\title{
LA RESOLUCIÓN DE UN LARGO DEBATE EN ESPAÑA. LA PLENA SUJECIÓN DEL DERECHO MILITAR A LA CONSTITUCIÓN Y LA SUPERACIÓN DE CLÁSICOS DUALISMOS SOBRE LAS FUERZAS ARMADAS
}

LORENZO COTINO HUESO

Universitat de València 


\section{SUMARIO}

I. El Derecho Y las neCESidades de La defensa. LAS PRETENSIONES del PRESENTE ESTUdio. 1. El necesario punto de partida: las necesidades de la defensa y las dificultades de fondo que se dan en la materia jurídico militar. 2. Los propósitos del presente estudio. II. LOS DUALISMOS EN LA PERCEPCIÓN DEL FENÓMENO MILITAR. 1. El dualismo en la concepción juridica de las Fuerzas Armadas. A) La existencia de un prolifero y atípico debate doctrinal en España. B) La verdadera importancia del debate: la mitigación de la fuerza normativa constitucional desde las posiciones institucionalistas. 2. El dualismo sociológico en la percepción de las Fuerzas Armadas y su interconexión con el dualismo jurídico-constitucional. De la normatividad de la ley de leyes al "modelo constitucional" de Fuerzas Armadas. III. RECHAZO DE UNAS "CONNOTACIONES INSTITUCIONALISTAS QUE MERMASEN LA NORMATIVIDAD CONSTITUCIONAL". 1. Cómo abordar la materia de forma adecuada. 2. La inicial significación de las teorías institucionalistas supondría cierta merma de la normatividad constitucional sobre lo militar. A) La perspectiva institucional clásica y la sujeción de la institución militar al Derecho. B) La perspectiva ordinamental clásica ya apuntaba la vinculación a la Constitución. 3. La evolución y significación actual de las teorias institucionalistas: la plena sumisión de las instituciones y los ordenamientos al Derecho y en concreto a la Constitución. A) El nuevo significado y alcance jurídico de la noción "institución». B) La relativización del alcance de los "ordenamientos". C) Las concepciones institucionalistas actuales conllevan la plena sujeción de la institución de las Fuerzas Armadas y del Derecho militar a la Constitución y el Derecho. 4. El sentido y alcance de las instituciones y los ordenamientos en el concreto marco constitucional español. A) La recepción constitucional española del institucionalismo y su significación positiva respecto de la normatividad constitucional. B) La sujeción de las instituciones a la ley de leyes y el Tribunal Constitucional. IV. LA

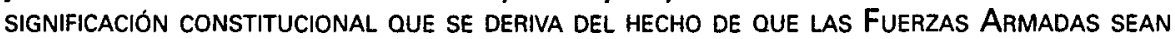
UNA INSTITUCIÓN JURIDICA. 1. El reconocimiento y alcance de las Fuerzas Armadas como institución. A) El acogimiento de las Fuerzas Armadas a los caracteres de una institución. B) ¿Se reconoce una garantía institucional sobre las Fuerzas Armadas? 2. La evolución de la caracterización jurídica de las Fuerzas Armadas por nuestro Tribunal Constitucional. 3. ¿Cuál es la significación jurídica del reconocimiento de las Fuerzas Armadas como una institución? 4. Unas notas al respecto de la institución militar a la que da vida jurídica la Constitución española. V. Una VISIÓn ESTRUCTURAL fORMAL. ¿PRESCRIBE EXPRESAMENTE LA CONSTITUCIÓN UNA PECULIAR SUJECIÓN PARA EL ÁMBITO MILITAR? 1. Un mismo propósito, unas nuevas coor* denadas. 2. La significación de la remisión a los "principios constitucionales" contenida en los artículos 8.2., y 117.5. $C E$; doctrina y jurisprudencia. A) La regla general del art. 9.1. ${ }^{\circ} \mathrm{CE}$ y sus especificaciones. B) La referencia a los "principios constitucionales" contenida en los arts. 8 y 117 CE para nuestra doctrina. C) La escasa atención del Tribunal Constitucional a las referencias de sujeción a los principios constitucionales. 3. La posición aquí sostenida: los arts. 8.2. y 117.5. ${ }^{\circ}$ CE evitan cualquier negación de la plena normatividad constitucional para el ámbito militar. A) La poca operatividad que podria alcanzar una lectura negativa de lo dispuesto en los artículos 8.2..$^{\circ}$ y 117.5. $\mathrm{CE}$. B) Una lectura positiva en virtud de la interpretación sistemática. VI. A MODO DE CONCLUSión: CONVERgencia social, CONVERgencia en Derecho. El Binomio Constitución-Fuerzas ARMADAS POR ENCIMA DE LO NORMATIVO. 


\title{
LA RESOLUCIÓN DE UN LARGO DEBATE EN ESPAÑA. LA PLENA SUJECIÓN DEL DERECHO MILITAR A LA CONSTITUCIÓN Y LA SUPERACIÓN DE CLÁSICOS DUALISMOS SOBRE LAS FUERZAS ARMADAS
}

\author{
POR

\section{LORENZO COTINO HUESO} \\ Universitat de València
}

\section{EL DERECHO Y LAS NECESIDADES DE LA DEFENSA. LAS PRETENSIONES DEL PRESENTE ESTUDIO}

1. El necesario punto de partida: las necesidades de la defensa y las dificultades de fondo que se dan en la materia jurídico militar

Cuando se trata del "sacrosanto" principio de conservación del Estado la realidad parece primar sobre el Derecho'. La institución mili-

1 Expresión contenida en Álvarez Garcia, Vicente, El concepto de necesidad en Derecho público, Civitas, Madrid, 1996, págs. 32-33. Esta monografía destaca en nuestro pais a la hora de abordar abstracta y juridicamente el principio de necesidad en el Derecho público - fuera del ámbito de lo penal- No obstante, este autor no aborda el Derecho militar como una expresión del principio de necesidad. He tenido ocasión de sostener en otro marco que "lo relativo a la defensa y a lo militar resulta una de las parcelas naturales de la necesidad y como lógica conse- 
tar, en tanto es la primordial encargada de la defensa del Estado, sólo parece haber quedado sometida históricamente a la razón de las armas, y no a las armas de la razón jurídica ${ }^{2}$. En el fondo de toda la cuestión jurídica alrededor de las Fuerzas Armadas subyace lo que afirmó el Diputado Solana Maradiaga: "La realidad es que estamos ante un hecho, y en los temas de la guerra, en los temas de la defensa, los hechos priman sobre cualquier otro planteamiento" ${ }^{3}$. A comienzos de siglo, Salcedo afirmaba que el principio del Derecho Público del que derivaban todas las normas jurídico-militares era "la necesidad de emplear la fuerza del Estado, convenientemente organizada, del modo más eficaz socialmente para defender [...] el Estado" "; así, el Ejército se concebía como una institución del Estado regida por normas que obedecen a un principio de necesidad superior a las leyes mismas.

El Derecho ha intentado encauzar juridicamente las necesidades de la defensa, tarea en modo alguno sencilla. Especialmente incómoda resulta la acomodación jurídica de la institución militar cuando se trata del Estado constitucionaF. Y esta singular dificultad deriva del hecho de que los principios y reglas propios a la naturaleza y funciones de los Ejércitos y las normas que en ellos rigen (eficacia, disciplina, jerarquía, neutralidad política, etc.) no siempre se avienen bien con los principios propios del Estado democrático de Derecho y los derechos fundamentales en él reconocidos. $Y$ es que la necesidad - la de llevar a cabo efi-

cuencia, es donde el Derecho encuentra sus mayores dificultades para ejercer su imperio. Cfr... El modelo constitucional de Fuerzas Armadas, Tesis doctoral, Valencia, 2000, págs. 392 y ss.

2 Afortunada expresión contenida en Blanouer, David V., Ciudadano y soldado. La Constitución y el servicio militar, Civitas, Madrid, 1996, pág. 26, perteneciente al prólogo de esta obra.

3 Así, el diputado socialista Javier Solana Madariaga en su intervención en defensa del artículo octavo del dictamen de la Comisión constitucional ante el Pleno del Congreso, cfr. Cortes Generales. Constitución española. Trabajos Parlamentarios, (4 vols.) Servicio de Estudios y Publicaciones de las Cortes Generales, Madrid, 1980, pág. 1970.

4 Cfr... SalCedo y Ruiz, Ángel, Sustantividad y fundamento del derecho militar, Discurso leído en el acto de su recepción en la Real Academia de Ciencias Morales y Políticas, con contestación a cargo de UGARTE Y PAGÉs, Javier, Real Academia de Ciencias Morales y Politicas, Madrid, 1913, cita de las págs. 31-32.

5 Al respecto del mismo, puede verse, entre otros, SÁnchez Ferriz, Remedio, El Estado constitucional y su sistema de fuentes, Tirant lo Blanch, Valencia, 2000. Sobre la difusión de la expresión puede seguirse, Pérez LuÑo, Antonio E. «Estado constitucional y derechos de la tercera generación", en Anuario de Filosofia del Derecho, n.․XIV, 1997, págs. 545-570. 
cazmente la defensa militar el Estado constitucional- comporta centralización y concentración tanto de los poderes que dirigen la fuerza militar, como dentro de las mismas Fuerzas Armadas, asimismo, la necesidad, y en concreto las exigencias de eficacia de la organización militar conllevan sobre sus componentes una merma de los derechos y libertades y sus garantías. Como es obvio, estos efectos reflejo de la necesidad colisionan con los principios que rigen un Estado de Derecho que asi lo sea.

Ahora bien, pese a que el Derecho militar quede inspirado intensamente por la necesidad, en modo alguno es la eficacia y la necesidad el único principio inspirador, ni dicho sea de paso, el único causante de la singularidad del Derecho militar ${ }^{6}$. En un Estado constitucional tan propios a las FAS y al Derecho militar son las exigencias de la necesidad como lo son las reglas y principios recogidos en la ley de leyes. $Y$ tan propio al Derecho militar como lo es la disciplina lo son las reglas y principios que rigen para las FAS (el "Derecho constitucional militarn) y las ubican en el Estado constitucional democrático cuya génesis y seguimiento han ocupado ya buena parte del estudio ${ }^{7}$. Lo que se precisa es armonizar los derechos y libertades, sin los cuales no hay Constitución con la disciplina militar, sin la cual no hay Ejército que pueda defender al Estado constitucional. Sin embargo, no resulta sencillo elaborar una construcción jurídica que armonice y optimice estos dos pies (disciplina-derechos) en los que, como algún autor advirtió, todo este tema se mueve ${ }^{8}$. Siguiendo esta metá-

- Los derechos y libertades de los militares quedan limitados por las exigencias de eficacia de la Institución militar, en especial por la disciplina. Ahora bien, no es en modo alguno la única causa de la limitación. La neutral posición política que debe guardar la Institución militar, y que puede comportar la limitación de las libertades públicas de sus miembros se legitima en beneficio de la calidad democrática del sistema político constitucional. De este modo, no es sólo la necesaria eficacia la que justifica una desvirtuación de los principios del Estado constitucional.

He tenido ocasión de abordar la especificidad y admisibilidad del ordenamiento castrense desde la perspectiva del principio de igualdad en Cotino HUESO, Lorenzo, La singularidad militar y el principio de igualdad: las posibilidades de este binomio ante las Fuerzas Armadas españolas del siglo XXI, CEC, Madrid, 2000

8 Fernández Flores, José L., "Los fundamentos el orden jurídico militar en el Estado Social y Democrático de Derechon, en la obra colectiva Libertades públicas y Fuerzas Armadas, Actas de las jornadas de estudio celebradas en el Instituto de derechos humanos de la Universidad Complutense, Madrid, 4-24 de febrero de 1984, presentación y edición a cargo de Luis Prieto y Carlos Bruquetas, Centro de 
fora, lo que no cabe duda es que el Derecho militar de un Estado constitucional no puede "cojear".

\section{Los propósitos del presente estudio}

Pretender averiguar qué se encierra tras las puertas de unos cuarteles es ya un importante esfuerzo para quien pretende abordar científicamente la institución militar. Más lo es, como advirtió Mancini, introducir en ellos la Constitución ${ }^{9}$, es decir, determinar cómo y en qué medida debe proyectarse la norma suprema en el mundo castrense. Diversos autores han reparado en esta dificultad y en la necesidad e importancia de esta tarea.

\section{García Herrera afirmó con acierto que:}

«Elaborar un marco teórico que proyecte en el seno del Ejército los principios institucionales democráticos, constituye un reto que no debe soslayarse. La urgencia de la reflexión deriva no sólo de la coherencia democrática, que persigue que el conjunto social se inspire y regule en conformidad con determinados valores y pautas de funcionamiento, sino también de la relevancia del papel que corresponde a los militares y de la ignorancia generalizada que existe de ellos" ${ }^{10}$.

Publicaciones del Ministerio de Educación y Ciencia, Madrid, 1985, págs. 263-274, en la pág. 266, este autor afirma: «me siento en la necesidad de hacer la prevención de que, todo mi tema, se mueve sobre dos pies: por un lado, la presencia del Derecho tal y como lo entiende la vigente legalidad española; por otro, las necesidades de la Institución militar, tal y como se ha entendido siempre y como hay que entenderla ahora, a la vista de nuestro tiempo y de nuestra situación. Prescindir del Derecho y de sus condicionamientos o prescindir de lo militar y sus exigencias, es andar a la pata coja, es contribuir a un orden jurídico militar ausente de la realidad, inservible para sus fines".

9 MancinI, Federico, "Equivoci e silenzi sul sindicato di polizia», en Revista Trimestrale di diritto e porcedura civile, 1975, págs. 286 y ss. Tal y como se afirma en Domínguez-Bernueta, Miguel y otros, Constitución, Policía y Fuerzas Armadas, Marcial Pons, Madrid, 1997, en su introducción (págs. 23-28), en concreto en la pág. 24, esta frase de "llevar la Constitución a los cuarteles", surge de cierta izquierda italiana, y si bien no queda exenta de demagogia, encierra una ardua tarea jurídica.

10 Cfr. García Herrera, Miguel A. "Estado democrático y libertad de expresión" (segunda parte), en Revista de la Facultad de Derecho. Universidad Complutense de Madrid, n. 65, primavera 1983, págs. 186-197, cita de la pág. 187. 
En esta línea se han efectuado notables esfuerzos", y en ella se inscribe el presente estudio.

Intentar afirmar la normatividad constitucional tras dos décadas de vigencia de la ley de leyes puede parecer, ciertamente, un afán inútil o, cuanto menos, anacrónico. Sin embargo, no lo es tanto, si se trata del alcance de la normatividad constitucional en el ámbito castrense $^{12}$. Esto es así, de un lado, porque siguiendo algunos posicionamientos doctrinales parece ponerse en duda la normatividad constitucional para este ámbito, cuanto menos en su plenitud. De otro lado, quien suscribe parte del convencimiento de que los dualismos que se dan a la hora de percibir el fenómeno militar (como se verá, tanto desde la perspectiva jurídica como sociológica) quedarían superados si se partiese de un enfoque propiamente constitucional, distanciado en lo posible de polarizaciones maniqueas de la realidad militar. La

11 Éstos pueden advertirse en la bibliografía que aqui se incluye. Particularmente, creo que pueden ser destacadas dos obras publicadas más recientemente; de un lado, la ya citada Constitución, Policía y Fuerzas Armadas, en la que constan diversos trabajos sobre la materia que han ido realizando los miembros del grupo que dirige el catedrático de Salamanca; de otro lado, especial referencia merece el trabajo de Blanouer, David V., Ciudadano y soldado... cit. A mi juicio, David Blanquer ha sido quien ha realizado el más serio esfuerzo hasta la fecha a fin de acomodar el Derecho militar al ordenamiento constitucional. No obstante, su extraordinario trabajo, presente en esta reflexión, se centra en el ámbito algo más concreto del estatuto de derechos y libertades del militar.

12 Una reciente visión retrospectiva de la evolución de las FAS y el Derecho militar desde la aprobación de nuestra ley de leyes puede verse en FAURA MARTín, José, "Las Fuerzas Armadas", en La Constitución española de 1978. 20 años de democracia, Congreso de los Diputados-CEC, 1998, págs. 237-264, así como en SuÁrez Pertierra, Gustavo, "La Administración Militar a lo largo de veinte años de vigencia de la Constitución", en Administraciones Públicas y Constitución. Reflexiones sobre el XX Aniversario de la Constitución Española de 1978, INAP, 1999, págs. 595-607 y, en la misma obra colectiva, MENÉnDEZ MENÉnDEZ, Adolfo, "Administración militar, Fuerzas Armadas y Cuerpos de Seguridad en la Constitución española de 1978", págs. 609-626. En dichos estudios se recoge, con carácter general, una visión positiva de tal desarrollo constitucional, con la cual no se puede menos que coincidir; nuestra ley de leyes supuso el punto de partida, mas los logros en la constitucionalización del ámbito castrense no pueden equipararse, a mi juicio, a los registrados en otras parcelas, dada la lentitud y retraso en su andadura. Cabe advertir, no obstante, que en la actualidad se registran variaciones legislativas: la aprobación de la nueva Ley Orgánica 8/1998, de 2 de diciembre, de Régimen Disciplinario de las Fuerzas Armadas, cuyas innovaciones bien pueden entenderse como técnicas; mayor importancia, aunque tampoco cuente con trascendentales cambios de fondo desde la perspectiva constitucional, tiene la reciente Ley 17/1999, de 18 de mayo, de Régimen del Militar Profesional. 
aspiración última del presente estudio es, pues, asentar las bases que impliquen la necesidad de partir del marco constitucional a la hora de abordar lo militar.

Las reflexiones que se contienen a continuación en absoluto implican un estudio meramente técnico o formal, exento de compromiso. Al menos, la posición de su autor es clara: asentar la normatividad constitucional sobre el ámbito castrense despeja el camino para acabar de adecuar a la institución militar española en el Estado social y democrático de Derecho (art. 1.1 CE). El esfuerzo intelectual de adaptar a los Ejércitos en la normalidad constitucional no es, ni más ni menos, que un paso más (si bien, decisivo) en favor de la plena convergencia del estamento militar con la sociedad a la que sirve. $Y$ es, precisamente, un verdadero reto ante el actual proceso de profesionalización que vive nuestro país ${ }^{13}$. Sólo quien admira tanto a las Fuerzas Armadas como a la democracia y a la libertad dedica su esfuerzo a su armonización y optimización. Sólo puede creer que esta tarea no es necesaria quien ignora que la democracia es por esencia perfectible.

\section{LOS DUALISMOS EN LA PERCEPCIÓN DEL FENÓMENO MILITAR}

Quien se aproxima a la literatura científica relativa a las Fuerzas Armadas (en adelante, "FAS") no puede dejar de percibir la presencia de dualismos. Tanto en la Sociología militar como en la literatura jurídico-constitucional se perciben dos tendencias, dos percepciones de un mismo fenómeno, el castrense. Una y otra dualidad de perspectivas sociológica y jurídica, como se verá, están claramente vinculadas.

13 En esta línea, puede verse mi trabajo Cotino Hueso, Lorenzo, "El reto de la profesionalización total de la Administración militar", comunicación presentada en las XIX Jornadas sobre la Administración Pública, (julio de 1997) organizadas por la Secretaría Técnica del Ministerio de Justicia. Estas jornadas han sido publicadas bajo el título Constitución y el nuevo diseño de las Administraciones estatal y autonómica, Civitas- $\mathrm{BCH}$, Madrid, 1998, el trabajo referido se corresponde con las páginas 289-312. Herrero de Miñón Miguel, “Dimensión constitucional de la profesionalización de las Fuerzas Armadas", en Revista de Derecho Político de la UNED, n.. 43, 1998, págs. 11-27, profundiza sobre la inquietud de aquel estudio, respecto del truncamiento del nexo Fuerzas Armadas-sociedad en virtud de la profesionalización militar. Una visión muy crítica del actual proceso, puede seguirse en GARCiA DE LA CRUZ, Juan J. "La sudoprofesionalización de la tropa", en Claves de la razón práctica, n. 82 , mayo de 1998, págs. 59-65. 


\section{El dualismo en la concepción jurídica de las Fuerzas Armadas}

\section{A) La existencia de un prolífero y atípico debate doctrinal en España}

Desde la aprobación de la Constitución española se ha suscitado un prolífero debate doctrinal en relación con la concepción jurídica de las FAS. Es bien posible que a ello haya contribuido la uanomalía (o más bien patologia constituyente en todo lo referente a temas del ordenamiento constitucional militar) ${ }^{14}$. En esta controversia se han dado, básicamente, dos posiciones: la institucionalista ${ }^{15}$ y la administrativista ${ }^{16}$;

14 Cfr... Férnando Pablo, Marcos M., "Ejército, policía y libertad sindical", en Revista de Política Social n. ${ }^{2} 44$, octubre-diciembre, 1984, ahora en Dominguez-BERRUeta, Miguel y otros, Constitución, Policia y Fuerzas Armadas, cit. págs. 402-450, cita de la pág. 417.

15 Así, encontramos la aceptación de la consideración institucional con diversidad de matices en Fernández Segado, Francisco, "La posición constitucional de las Fuerzas Armadas", en Revista Española de Derecho Militar, año 1993, enerojunio, págs. 13-71, págs. 36 y ss.; SerRano AlberCA, José Manuel, "Comentario al artículo octavo", en Garrido Falla, Fernando (dir.), Comentarios a la Constitución, (2. ed. ampliada), Civitas, Madrid, 1985, págs, 123-143., págs. 124 y 129 y ss.; TriLLo-FIGUEROA, "Las Fuerzas Armadas en la Constitución española (Esbozo de una construcción institucional)", REP, n. 12, noviembre-diciembre de 1983, págs. 105-140, in toto; LópEZ-GARRIDO, Diego, "La posición constitucional de las Fuerzas Armadas", $R A P$, números 100-102, enero-diciembre de 1983, págs. 949-971, in toto; LAFUENTEBalle, José María, El Rey y las Fuerzas Armadas en la Constitución, EDERSA, Madrid, 1987, págs. 344 y ss.; ElorRIAGA, Gabriel, «El artículo 8 de la Constitución y la institución nacional de las Fuerzas Armadas", en AA. VV, Jornadas de Estudio sobre el Título Preliminar de la Constitución, 1988, Madrid, Ministerio de Justicia, Centro de Publicaciones de la secretaria General Técnica. Tomo IV, págs. 2547-2559, in toto, (concretamente este autor afirma que las FAS son una uinstitución de la Administración»). En esta misma obra, Martínez LóPEz-MuÑIz, José L. en "Fuerzas Armadas y administración pública", págs. 2701 a 2725, in toto. Más reicentemente y en la versión más extrema del institucionalismo, Parada VÁzouez, prólogo a la obra de Domínguez-Berrueta, Miguel y otros, Constitución, Policia y Fuerzas Armadas, cit. in toto. Entre las últimas aportaciones, en un sentido institucionalista que puede tildarse de "moderado", Cosculluela Montaner, Luis, "Prólogo" a Peñarrubia Iza, Joaquín M., Presupuestos constitucionales de la Función militar, CEPC, Madrid, 2000, págs, 19-22, en concreto, pág. 20 , cabe advertir que de esta obra ha tenido conocimiento quien suscribe en las últimas pruebas de imprenta de esta publicación.

${ }_{16}$ La naturaleza administrativa de las FAS es mantenida por diversos autores. Así, Guaita Martorell, Aurelio, "Los derechos fundamentales de los militares", Libro homenaje al profesor Villar Palasi, Cívitas, Madrid, 1989, págs. 577-589.Ya en 1952 este autor defendía la naturaleza administrativa de las FAS, ver, "La Administración militar", en Revista de Administración Pública, n.7, 1952, págs. 105-122. Con no pocos matices institucionalistas, pero concibiendo a las FAS en el marco de la Administración, también en tiempos pasados OraA Rodriguez, Luis, "Derecho de peti- 
en todo caso, no han faltado terceras vías en tal polémica ${ }^{17}$, así como

ción en las Fuerzas e Institutos armados", Revista Española de Derecho Militar, n. ${ }^{9}$ 19, enero-junio, 1965, págs. 39-70. LóPEz HeNAREZ, Vicente, "La Administración militarn, Revista Española de Derecho Militar, n. 19 , enero-junio, 1965, págs. 71-88.

Desde la aprobación de la Constitución, las tesis administrativistas se han defendido por BARCELONA LLOP, Javier, "La organización militar: apuntes jurídicoconstitucionales sobre una realidad estatal", Revista de Administración Pública, 110, mayo-agosto de 1986, págs. 55-105 in toto; LóPEz RAMÓn, Fernando, La caracterización juridica de las FAS, Centro de Estudios Constitucionales, Madrid, 1987 in toto: BLANCO VAlDÉs, Roberto, La ordenación constitucional de la defensa, Tecnos, Madrid, 1988, págs. 61-71; Blanquer, David, Ciudadano y soldado... cit. págs. 215218 y 233-236 y, así como, por último, LÓPEz BENiTEz, Mariano, Naturaleza y presupuestos constitucionales de las relaciones especiales de sujeción, Civitas, Madrid, 1994, pág. 308 y ss. si bien, como a continuación se sigue su análisis puede incluirse en el marco institucionalista y en el del orden interno de Schmitt.

17 Dominguez-BerRueta, Miguel, y otros, en "La organización administrativa de la defensa (la reforma de la organización central de la defensa en España)", en AA. VV, Jornadas de Estudio... cit., págs. 2907-2951, y del mismo autor, también en esta obra, «El control jurídico-constitucional de la transición militar», en AA. VV, Jornadas de Estudio... cit., págs. 2955-3006 y Nevado Moreno, Pedro T., La función pública militar, con estudio Preliminar de Ramón Parada Vázquez, Marcial Pons, Madrid, 1997. págs. 37 a 46 . La postura mantenida por dichos autores, como veremos, puede considerarse, no obstante, dentro de una preponderancia de las coordenadas administrativistas. No sucede lo mismo con MARTinez López-MUÑIz, José L., "Fuerzas Armadas y administración pública", en AA. VV, Jornadas de Estudio sobre el Título Preliminar de la Constitución, 1988, Madrid, Ministerio de Justicia, Centro de Publicaciones de la Secretaría General Técnica. Tomo IV, págs. 2701-2725, in toto quien sostiene la categorización de las FAS como "Fuerza ejecutiva pública" a resultas de la cual las consecuencias tienen un fuerte carácter institucionalista. Hace poco, esta posición ha sido seguida por Fernández-PIÑeYro y Hernández, Emilio, "Las nuevas Delegaciones del Ministerio de Defensa y la estructura de la Administración periférica del Estado (A propósito de la Disposición adicional primera de la Ley 6/1997, de 14 de abril, de Organización y Funcionamiento de la Adminstración General del Estado, LOFAGE)", comunicación presentada en las XIX Jornadas sobre la Administración Pública, (julio de 1997) organizadas por la Secretaría Técnica del Ministerio de Justicia. Estas jornadas han sido publicadas bajo el título Constitución y el nuevo diseño de las Administraciones estatal y autonómica, Civitas-BCH, Madrid, 1998, en concreto págs. 165-169, quien niega que las FAS formen parte de la Administración militar.

De otra parte, recientemente, HeRrero de MiÑón Miguel, "Dimensión constitucional de la profesionalización...." cit., págs. 11-27 ha dedicado algún espacio a esta vieja discusión, aportando alguna luz nueva. Herrero, en las págs. 26 y 27 , señala que prefiere recurrir a la categoría de "orden concreto" que Schmitt formulara para superar la disyuntiva entre normativismo y decisionismo como criterios de interpretación constitucional. Es el orden concreto, como entramado de relaciones constitutivas de un conjunto, lo que permite entender la indole de las Fuerzas Armadas y también, dicho sea de paso, de la administración civil y de sus grandes cuerpos si éstos han de conservar el espíritu diferencial que garantiza su capacidad de servicio. Bajo esta perspectiva, Herrero defiende la oportunidad de unos valores particulares en orden de una mejor prestación del servicio que la sociedad demanda. 
posiciones en cierto modo integradoras ${ }^{18}$.

Cabe señalar que este autor hace referencia a la obra del alemán, recientemente traducida, ScHMrT, Carl, Sobre los tres modos de pensar en la ciencia juridica (con estudio preliminar, traducción y notas de Montserrat Herrero), Clásicos del Pensamiento (Tecnos), Madrid, 1996. En la misma se incluyen valiosas reflexiones en las que se advierte el peso y éxito de las consideraciones institucionalistas de Hauriou y Santi Romano.

Por su parte, actualmente, MENÉndez MENÉndez, Adolfo, "Administración militar..." cit. (subsecretario de Defensa) lo que subraya desde un inicio es la "naturaleza eminentemente instrumental» de las FAS. Sin examinar expresamente al debate, aunque subyace claramente en sus afirmaciones, señala que "tras los veinte años de vigencia de la Constitución [...] puede afirmarse que su artículo 97 no ha sido condicionado en modo alguno por el polémico art. 8 sino que, es este último el que, a todos los efectos, se ha interpretado y desarrollado a partir de lo previsto por aquél.». Ver, ob. cit. pág. 610. Esta posición parecía señalarse incluso en el trabajo de Fernández Flores, José L., "Los fundamentos el orden jurídico militar en el Estado Social y Democrático de Derechon, cit. cuando afirmaba la necesidad de mantener "el específico orden militar interno", cit. pág. 272, sin mayor reflexión sobre el particular. López Benítez, que si bien se acaba de incluir entre los administrativistas, en su excelente trabajo sobre las relaciones de especial sujeción, ahi citado, parece inspirado tanto por el funcionalismo como por la existencia de un orden interno cuando, entre otros, afirma sobre la permanente peculiaridad de ciertas relaciones jurídico administrativas, que no son particulares de España ni de ninguna época, sino que "están en la propia naturaleza de las cosas, en la atmósfera jurídica que respira y alimenta el ordenamiento" (ver, ob. cit. pág. 350).

18 Así, Suárez Pertierra, Gustavo, "Regulación jurídico-constitucional de las Fuerzas Armadas", Conferencia inaugural presentada en las Jornadas de Estudio... cit. págs. 2361-2414, en aquel momento, tal autor ostentaba el cargo de Subsecretario de Defensa. En la actualidad, dicho autor resuelve la polémica afirmando que la naturaleza de las FAS no se deduce del artículo 8 , dedicado a constitucionalizar las misiones de los ejércitos, sino del artículo 97, en el que se dispone que éstos forman parte de la Administración, así en SuÁrez PerTIerRA, Gustavo, "La Administración Militar a lo largo de veinte años..." cit. págs. 597-598.

Con cierto eclecticismo aunque con inclinación institucional, tanto CASADO Burbano, Pablo, "Las Fuerzas Armadas en la nueva Constitución Española», en Revista Española de Derecho Militar (REDM) n. 36, julio diciembre de 1978, págs. 741 , concretamente en las págs. 9 y 25 y ss., donde considera a las FAS como una "administración institucional" del Estado, como RoorigUez-VILLASANTE Y PRIETO, José L., en "La Ley 17/1989, de 19 de julio, reguladora del régimen del personal militar profesional (Ley de la función militar", en Revista Española de Derecho Militar n.. 54, julio-diciembre de 1989, págs. 167-205, en concreto véanse las págs. 167 a 173. También, Quiroga de Abarca, José María, "La Administración militar y su responsabilidad patrimonial", Montecorvo, Madrid, 1988 quien afirma que se trata de una Administración especial de la Administración del Estado cuya finalidad es prestar un servicio público, la defensa del Estado (ver págs. 259 y ss. y 325 y ss.). Por su parte, muy recientemente, Peñarrubia IZA, Joaquín M., Presupuestos constitucionales de la Función militar, cit. págs. 51 y ss. si bien dedica a la cuestión varias páginas con carácter descriptivo, se postula tímidamente mediante una posición integradora de tendencia más administrativista: "Se puede afirmar que las Fuerzas 
Debe señalarse en primera instancia que la polémica ha sido atípica ${ }^{19}$, velada ${ }^{20}$, en apariencia vacía ${ }^{21}$, a la par que posiblemente sobredimensionada 22 .

Armadas no son una institución, en el sentido que a este concepto se ha dado en Derecho público, sino sólo una parte de la Administración pública, pero también se puede decir que la misma Administración pública es una institución $v$, entonces, también lo serán las Fuerzas Armadas".

19 Tal debate doctrinal no deja de resultar extraño a quien se interesa por la materia militar; la polémica en sí guarda unos caracteres que permiten calificarla, cuanto menos, como atípica. $Y$ es que pese a lo prolífero de la contienda intelectual, algunos de entre quienes se han posicionado han puesto en duda su centralidad y proyección jurídicas, si bien, ello no les ha impedido decantarse por una u otra posición. No resulta sencillo comprender cómo, una cuestión que se juzga como estéril jurídicamente, ha suscitado tan prolifera polémica. La propia existencia del debate impele a considerar que algo subyace tras él.

Asi, López Ramón, Fernando, La caracterización jurídica...cit. págs. 368-369, afirma que: "sostener en la actualidad que las Fuerzas Armadas son una institución no constituye una operación interesante bajo una óptica jurídica. No hay consecuencias, el concepto no sirve para identificar un determinado régimen juridico". En este sentido, cabe recordar que López Ramón dedica para ello toda su ejemplar obra. Ciertamente, la irrelevancia jurídica de la cuestión es, propiamente, una de las conclusiones de su posicionamiento en tal debate. Tal es así, que afirmar la esterilidad o inocuidad del mismo conlleva la aceptación de no pocas premisas, la cuales tienen una ineludible proyección jurídica.

${ }_{20}$ Debe advertirse la falta de acierto de gran parte de los trabajos relativos a este dualismo jurídico institucionalistas-administrativistas. $Y$ es que la mayoría de estos estudios no han manifestado con claridad las importantes consecuencias que se pueden derivar del acogimiento de un postulado institucionalista o uno administrativista.

21 BLANCO VALDÉs, Roberto, La ordenación constitucional... cit. págs. 66-67, afirma que "Esta polémica doctrinal administración versus institución [...] presenta una doble quiebra que la convierte a la postre en realmente intrascendente a la hora de fijar la posición de las Fuerzas Armadas en nuestro sistema constitucional. [...] La polémica es no sólo confusa desde el punto de vista teórico [...] sino, además, casi irrelevante desde el punto de vista práctico, es decir, el de la concreta interpretación constitucional".

Más recientemente, en la línea de lo mantenido en su trabajo antes citado se ha pronunciado por la irrelevancia jurídica de la cuestión Rodríguez VILLASANTE, José L. en los encuentros celebrados en el marco de los Cursos de Verano de El Escorial, organizados por la Universidad Complutense de Madrid los días 28-29 de agosto de 1997; concretamente en su participación con título uLos derechos fundamentales del militar y la profesionalización de las FAS". Por último, Herrero DE MiNón Miguel, "Dimensión constitucional de la profesionalización..." cit. pág. 26 ha señalado que esta polémica "puede resultar estéril si de ella no se deducen consecuencias prácticas".

Por el contrario, como recientemente ha apuntado SuÁREz PerTierRa, Gustavo, "La Administración Militar a lo largo de veinte años..." cit. pág. 597, "No es éste, como pudiera parecer, un problema meramente académico".

22 La falta de claridad en la percepción de la importancia del debate ha supuesto que, en ocasiones, la propia polémica se haya alimentado a sí misma. Así, 
Además, esta polaridad teórica institucionalistas / administrativistas ha adquirido en España connotaciones políticas, en tanto que se ha relacionado con la recepción constitucional del clásico principio de supremacía civil ${ }^{23}$. Lo que parece haberse debatido básicamente a través de las posiciones administrativa o institucional, es la posibilidad de que el poder militar haya sido, en alguna medida constitucionalizado ${ }^{24}$.

la doctrina ha dedicado notables esfuerzos en categorizar a las FAS como institución, administración, poder público, fuerza ejecutiva pública, etc. Sin embargo, llegado el punto de deducir unas consecuencias de las diversas categorizaciones, existen sorprendentes silencios

Trillo, por ejemplo, simplemente concluye toda su exposición significando que de lo único que se trataba era de afirmar tal carácter $y$ de negar que las FAS sean Administración. Cfr... Trillo-FigueroA, "Las Fuerzas Armadas en la Constitución española...." cit. pág. 150.

23 Agüero define la supremacia civil como "capacidad de un gobierno civil democráticamente elegido para llevar a cabo una política general sin intromisión por parte de los militares, de definir las metas y la organización general de la defensa nacional, formular y llevar a cabo una politica de defensa y supervisar la aplicación de la política general». Cfr... AgüEro, Felipe, Militares, Civiles y democracia. La España postfranquista en perspectiva comparada, Alianza Editorial, Madrid, 1995, pág. 48.

Al respecto del poder militar y la supremacía civil, por todos BLONDEL, Jean, Introducción al estudio comparativo de los gobiernos, (Trad. por Fernando Calleja), Revista de Occidente, Madrid, 1972, págs. 469-490, DE VERGoTTINI, Giusseppe, Derecho Constitucional Comparado, Espasa Calpe, Madrid, 1983 págs. 693 y ss., del mismo autor, "El Estado Militar", en Palomino, José F. y BidarT, Germán J. (Coords.) La jurisdicción militar y Constitución en Iberoamérica, Libro-Homenaje a Domingo Garcia Belaunde, Instituto Iberoamericano de Derecho Constitucional/Grijley, Lima, 1997, págs. 233 a 252. En España, entre otros, López RAMón, Fernando, La caracterización jurídica... cit. y Ballbé, Manuel, Orden público y militarismo en la España constitucional, Alianza Universidad, Madrid, 1983.

24 Los postulados institucionalistas pueden dar pie a sostener interpretaciones del texto constitucional regresivas respecto de este principio de supremacía civil. Asi lo advierte expresamente BARCELONA LLOP, Javier, "La organización militar...» cit. pág. 77, quien pone de manifiesto cómo la vía interpretativa institucionalista "llevada hasta sus últimas consecuencias pudiera arribar, incluso, a resultados contradictorios con la proclama de subordinación absoluta y sin grietas de lo militar al poder civil».

Una construcción institucionalista conllevaría interpretar que las FAS (reguladas en el Título Preliminar) son una institución y, por tanto, no son la "Administración militar" que el artículo 97 somete claramente a la dirección del Gobierno; en razón de ello, el mando supremo de las FAS que preceptúa el artículo 62 . $h$ / CE cobraría una virtualidad material y no meramente simbólica o formal. Mediante esta lectura institucionalista se fomentarían, pues, las teorías del poder de mando militar que tuvieron especial vigencia en el siglo pasado. Así, quedaría legitimado constitucionalmente un dualismo entre el poder civil y el poder militar. $Y$ no se trata en modo alguno de una hipótesis alejada de de la realidad de nuestra transición. Antes 
En el presente estudio el dualismo de las FAS como institución o Administración no se opera el análisis desde tal perspectiva política. De una parte, por que se ha tenido ocasión de abordar este punto de vista en otros trabajos ${ }^{25}$. De otra parte, porque se sobreentiende que es la propia Constitución la que reconoce la supremacía civil y la subordinación militar ${ }^{26}$. Por ello, la "supremacía civil" sobre el poder militar se

al contrario, como recuerda Busouets, Julio, Militares y demócratas. Memorias de un fundador de la UMD y diputado socialista, Plaza Janés, 1999, págs. 296-297, "algo que deseaban algunos sectores que no acababan de digerir la democracia" era la "peregrina teoría [por la cual] el Estado debía organizarse bajo la dirección suprema del Rey, del que dependian directamente, y en el mismo nivel, el jefe del Gobierno para todos los asuntos civiles y el jefe de las Fuerzas Armadas para los militares". En breve, sobre el tema, puntualmente, Cotino HUESo, Lorenzo, "La posición del Rey durante la situación vivida el pasado 21 de febrero de 1981", en El Titulo II de la Constitución. La monarquía parlamentaria. VII Jornadas de Derecho parlamentario, Cortes españolas, Madrid, 2001.

Por contra, desde un posicionamiento administrativista, el artículo 97 adquiriria plena e incuestionable virtualidad. Así, las FAS, como integrantes de la "Administración militar" del Estado, quedarían expresamente sometidas a la dirección del Gobierno. En consecuencia, tanto en éste como en diversos preceptos del texto constitucional habrían quedado recogidos el corolario de efectos que tradicionalmente se incluyen dentro del más genérico principio de la supremacia civil democrática.

${ }_{25}$ Al respecto puede verse mi estudio, Cotino HuEso, Lorenzo, «El principio de supremacía civil: perspectiva histórica y recepción constitucional", en Cuadernos Constitucionales de la Cátedra Fadrique furió Ceriol, $n .{ }^{\circ} 17$, perteneciente a otoño de 1996, publicado en septiembre de 1997, págs. 89-136. Hay que advertir, por cuanto al objeto del presente trabajo, no obstante, que en aquel articulo se seguian posiciones más próximas a los administrativistas, que ahora, con una mayor maduración y profundidad se modulan y compatibilizan con un adecuado entendimiento del institucionalismo jurídico, todo ello como lógico proceso de maduración de la tesis doctoral inicialmente citada, de próxima publicación parcial Cotino Hueso, Lorenzo, El modelo constitucional de Fuerzas Armadas, Ministerio de Defensa, Madrid, 2001.

26 No resulta difícil constatar la recepción jurídico-constitucional del principio de supremacía del poder civil respecto del militar y no cabe duda que la Constitución española de 1978 cubre sobradamente las exigencias convenidas por la doctrina. Para ello, en primer lugar, hay que dejar de lado vacías disquisiciones sobre la ubicación del art. 8 CE (que recoge la regulación básica de las FAS) en el Título Preliminar, pues la significación jurídica de dicha ubicación (simbolismos al margen) no es otra que la de someterse a un régimen de reforma constitucional rígido (art. 168.1 CE).

Para apreciar la recepción del principio de supremacía civil y sus derivaciones basta constatar las concreciones de este principio en nuestra norma suprema. Para ello, se puede seguir una combinación de los parámetros que establecen $\mathrm{DE}$ Vergottini, Giussepe, Derecho Constitucional Comparado, cit., en las págs. 296-301 (y en la obra antes citada) y LóPEz RAMÓN, Fernando "Principios de la ordenación 
hace depender en última instancia de la "supremacia constitucional» (pues es la propia ley de leyes la que reconoce la primacía civil) ${ }^{27}$.

Así pues, el presente estudio se centra en el dualismo jurídico FAS institución / Administración por cuanto su proyección respecto de la plena normatividad de la Constitución para el ámbito militar.

constitucional de las Fuerzas Armadas", en Estudios sobre la Constitución española. Homenaje al profesor Eduardo Garcia de Enterria, Vol. III., págs. 2547-2596. Asi, se constata la supremacia civil en la Constitución española, pues están reconocidos y salvaguardados los siguientes parámetros:

1.. Principio de legitimidad democrática del poder (art. 1.2 CE).

2.. Principio de neutralidad política de las FAS (arts. 28 y 29, y 70.1 E) CE).

3. ${ }^{-}$El poder político (civil) escoge los principios reguladores de la Constitución militar (art. 8.2 CE, remitiendo a los "principios constitucionales" para la regulación de las bases de la organización militar.)

4. - La intervención de las FAS debe darse únicamente a petición del poder político $y$, en su caso, la propia norma fundamental recoge las misiones que competen a la institución armada (arts. 8.1, 63.3 y $97 \mathrm{CE}$ ).

5. - Las constituciones reconocen un "alto mando" de las FAS al Jefe del Estado. En los ordenamientos con gobierno parlamentario tal competencia no implica atribuciones de mando militar en sentido técnico, ni atribuciones de orientación política (art. 62 h) CE); en cambio, en los sistemas presidencialistas tal alto mando sí supone facultades de orientación.

6.- Carácter estatal de las FAS. Monopolio estatal absoluto de los poderes de coerción. De ahí se desprende la prohibición de las milicias de los partidos y de las milicias locales - sin perjuicio de la posibilidad de diversos modos de descentralización- (art. 22.5 CE en relación con el 149.14 . $^{\text {a }}$ CE, y el 103.1 CE).

7..$^{2}$ Separación orgánica entre las FAS y las Fuerzas y Cuerpos de Seguridad del Estado (arts. 8 y $104 \mathrm{CE}$ ).

8. Limitación del ámbito de la jurisdicción militar - de existir ésta- al ámbito propio de lo castrense (art. 117.5 CE).

9. Fijación y limitación constitucional del régimen de los estados excepcionales (arts. 55.1 y. $116 \mathrm{CE}$ ).

En el libro producto de mi tesis doctoral, se dedican más de doscientas páginas a la constatación concreta de todos estos aspectos, en el tercer capítulo titulado "La posición que corresponde a las Fuerzas Armadas en el sistema político diseñado por la Constitución".

27 Blanouer, David, Ciudadano y soldado... cit. pág. 88 recuerda la clara vinculación entre supremacía civil y supremacía constitucional, al señalar que "la clave para garantizar la subordinación del poder militar al civil radica en la negación de la autonomía del ordenamiento militar y la proclamación de su sometimiento al ordenamiento general". Se reitera esta idea en su conclusión número uno, pág. 747: "La afirmación de que las Fuerzas Armadas se guían por los mismos príncipios jurídicos que el resto de las Administraciones Públicas conduce a consolidar la sujeción de los militares a la Constitución y al Poder Civil». 
Hay que señalar, también, que el problema fundamental de esta disputa ha sido que las importantes consecuencias políticas que podian derivarse de según qué posiciones han polarizado y deformado el tratamiento jurídico de la materia innecesariamente. Triepel, quien con tanto acierto criticase la rigidez formalista de la doctrina del Derecho público alemana, en tiempos difíciles se postulaba con claridad por la vinculación del Derecho público con la política, pero siempre con criterios jurídicos públicos y bajo el método del Derecho. Diría el alemán que uel Derecho público no tiene absolutamente otro objeto que lo político. El profesor de Derecho público no puede, por tanto, renunciar a analizar los fenómenos o intenciones políticas con criterios jurídicopúblicos ${ }^{28}$. Lo que ello no puede conllevar es a deformar los criterios jurídicos propios o del adversario para alcanzar el fin pretendido. $Y$ en este debate institucional/administrativo se aprecia en muchas ocasiones este fenómeno.

\section{B) La verdadera importancia del debate: la mitigación de la fuerza normativa constitucional desde las posiciones institucionalistas}

El debate central de los institucionalistas frente a los administrativistas se basa, desde mi punto de vista, en admitir o no la existencia de un "ordenamiento jurídico militar, entendido como un sector del ordenamiento inmune o situado al margen de sus más globales valores informadores" ${ }^{29}$. Desde un punto de vista institucionalista se trata-

28 TriePel, Heinrich, Derecho público y política, Civitas, Madrid, 1974, pág. 42.

29 Cfr... Dominguez-Berrueta, Miguel y otros, "El control jurídico-constitucional..." cit., pág. 2990. Este autor ha afirmado que para una perspectiva jurídica institucionalista:

«El Texto fundamental se limitaría a reconocer aquella histórica institución, con su peculiar modo de existencia, sus propios valores y "su ordenamiento jurídico peculiar"... estableciendo como únicos límites (externos) lo que el propio artículo 8-2 CE enuncia como "principios de la Constitución" [...] la vinculación cons. titucional seria la propia de una "vinculación negativa" respecto de sus peculiaridades jurídicas, es decir, sería posible mantener todos los rasgos propios, en tanto en cuanto no choquen de modo directo $y$ frontal con preceptos, valores o principios constitucionales [...] Por el contrario, rechazando la connotación institucionalista, se llega mas fácilmente a la idea de "vinculación positiva" a la Constitución".

Dominguez Berrueta es, a mi juicio, el autor español que en con mayor acierto ha captado la necesidad de afrontar el plano jurídico militar como un problema 
ría, siguiendo la metáfora inicial de este estudio, de dejar "cojo" al ordenamiento militar al no asumir que éste no sólo se inspira por la necesidad (eficacia, disciplina, etc.), sino también en el resto de los contenidos constitucionales.

Un claro ejemplo de una visión institucional así entendida nos lo ha proporcionado no hace mucho Parada Vázquez, quien afirma que la Constitución reconoció la institución particular de las FAS y todas sus exigencias propias a su naturaleza "para rebajar o excepcionar, asimismo, la aplicación de los derechos fundamentales de los militares, así como para garantizar su perfil institucional e impedir que el legislador ordinario pudiera alterar el núcleo tradicional del derecho militar" ${ }^{30}$. Por este medio se "aunaban las ventajas de respetar el principio de sujeción de las Fuerzas Armadas al Gobierno democrático con unas peculiaridades estructurales que son garantía esencial para su eficacia operativa y una defensa frente a su instrumentalización politico-partidaria" ${ }^{31}$. Todo ello tenía como punto de partida el artículo octavo de la Constitución que a su juicio fue corrompido con los gobiernos socialistas. Este precepto, como advertirian otros autores, sirvió para hacer efectiva una suave transición militar y una amortiguación de la vigencia de la ley de leyes en el marco militar, pues lo cierto es que el institucionalismo frenó la aplicación de la Constitución para el ámbito militar ${ }^{32}$.

Desde una perspectiva jurídico-institucional no se llega a afirmar que el ordenamiento militar pueda contravenir la Constitución, lo que sería de todo punto insostenible ${ }^{33}$. Sin embargo, la afirma-

más de interpretación e integración del marco constitucional -ver págs. 2994 y ss. - Tal y como aquí pretende subrayarse, a mi juicio, la cuestión no debe centrarse en la consideración de las FAS como administración o institución, sino que más bien se trata del ejercicio acertado de la ponderación de derechos, bienes y valores constitucionales y de la necesidad de que en tal actividad se tengan en cuenta una serie de pautas que con carácter general el mismo Tribunal ha desarrollado jurisprudencialmente.

3o Parada Vazouez, prólogo a la obra de Dominguez-Berrueta, Miguel y otros, Constitución, Policía y Fuerzas Armadas, cit. pág. 10.

${ }^{31} \quad$ Ibidem pág. 11.

32 "Introducción. La Constitución y el ordenamiento militar" (sin referencia al autor), en Domínguez-Berrueta, Miguel y otros, Constitución, Policía y Fuerzas Armadas, Marcial Pons, Madrid, 1997, págs. 23-28, pág. 24.

33 Blanco Valdés, Roberto, La ordenación constitucional... cit. págs. 24-25, no duda en reconocer la legitimidad de la existencia de un ordenamiento militar al margen del civil. Bajo este planteamiento que aqui no se comparte, lo que afirma este autor es que lo que corresponde al Estado constitucional es ureducirlo al mínimo" (ver, pág. 24). 
ción de que las FAS son una institución parece resultar por sí de peso para subrayar el principio de necesidad, $y$ no el resto de contenidos constitucionales. Desde las posiciones institucionalistas, se sostiene de forma más o menos abierta una relativización del alcance de la normatividad constitucional para el mundo de los cuarteles $^{34}$. Bastaría con que las FAS acatasen políticamente la Constitución, pero en modo alguno que sus contenidos hubiesen de constatarse en ella ${ }^{35}$.

La consideración institucional, tal y como se sigue con detenimiento, viene a suponer a modo de una "autoderogación" implícita o explícita de la Constitución para el ámbito militar. Por contra, bajo un soporte juridico mayormente formalista o estructuralista, el sostenimiento del carácter administrativo de las FAS implica una sujeción más estricta a los enunciados constitucionales ${ }^{36}$. En este sentido, desde las

34 A riesgo de excesiva simplificación, puede afirmarse que el institucionalismo juridico da cobertura a un entendimiento del Derecho como receptor de la peculiaridad castrense. Al situarse el Derecho como receptor de todo aquello propiamente militar se desprendería una cierta inmutabilidad de la Institución militar. Esta institución resultaría ser una realidad previa que el Derecho simplemente conforma y brinda su protección jurídica.

De este modo, podría incluso admitirse la permanencia y reconocimiento de unos principios, valores y particularidades propias de las FAS aun cuando resultasen difícilmente compatibles con los propios mandatos, principios y valores constitucionales. En consecuencia, parece cuestionarse la completa normatividad de la ley de leyes sobre la singularidad militar.

${ }_{35}$ Un claro ejemplo de esta perspectiva, entre otros, puede seguirse en FERnÁNDEZ Flores, José L., "Los fundamentos el orden jurídico militar en el Estado Social y Democrático de Derecho", cit. pág. 272 cuando afirma "que el Ejército sea democrático es que acate la constitución, y no otra cosa. Un Ejército que acata la Constitución democrática, pero en modo alguno, un Ejército que esté organizado internamente de modo democrático, puesto que esta democracia es incompatible por esencia con la esencia misma del Ejército, que es disciplina, jerarquía y unidad. Que es mando y rechaza la igualdad en los grados y que es opuesto a toda opción, en cuanto pluralidad de opciones, en el aspecto político."

36 A diferencia de la visión jurídico -institucional, desde los postulados administrativistas se rechazaria radicalmente la existencia de un ordenamiento jurídico separado del ordenamiento general. Sin embargo, afirmar el carácter administrativo de las FAS, puede comportar una indeseable rigidez formal, al exigir el reconocimiento expreso de toda peculiaridad del Derecho militar. Tal visión administrativista estricta exigiría justificar cualquier modulación con expresiones constitucionales (asi, por ejemplo, la disciplina militar sólo tendria cabida en tanto en cuanto resulta expresamente reconocida en los arts. 28 y $29 \mathrm{CE})$. 
filas institucionalistas se han defendido las posiciones como si considerar a las FAS Administración supusiese un atentado a la necesaria eficacia de la fuerza militar y un desconocimiento de sus caracteres propios. Desde las filas administrativistas se han defendido las posiciones como si la única forma de atar a las FAS y al Derecho militar a la Constitución y al poder civil fuese señalando su carácter de Administración. Como aquí se sostiene, y en modo alguno ello supone ningún posicionamiento ecléctico, que las FAS sean una institución jurídica no es incompatible con el hecho de que en España se hayan constitucionalizado en el marco de la Administración militar y, sobre todo, que el hecho de que sean una institución conformada por un ordenamiento propio, de ninguna manera relaja su vinculación con la Constitución.

A mi juicio, mediante este dualismo jurídico (institución-administración) se han canalizado dos posiciones respecto de la evolución y compatibilización de las FAS a los Estados democráticos de Derecho. Parece haberse instrumentalizado así la dificultad que entraña la adaptación de las FAS al Estado constitucional y los diferentes grados de exigibilidad de este necesario proceso de adecuación. Asi, la plena sujeción constitucional que subraya la consideración administrativa de las FAS implicaría la exigencia de una total puesta en contexto de la Administración militar con el marco jurídico político constitucional. Por contra, considerar a las FAS como institución implicaría admitir un distanciamiento castrense del contexto jurídico político general que la ley de leyes establece.

Blanquer, conjuntamente con Dominguez Berrueta, Fernández de Gatta y Nevado Moreno, en sus diferentes trabajos, sigue un riguroso formalismo al exigir que la Constitución de forma expresa la que reconozca las peculiaridades constitucionales militares. Así, en la pág. 103 se afirma que «toda particularidad o especialidad [...] debe ser susceptible de hallar justificación y fundamentación expresa en la propia Constitución" (en la misma dirección, véase el capitulo 3 del libro o la pág. 411 del mismo). Al respecto véase lo afirmado en mi comentario a la obra conjunta de éstos en la Revista de Estudios Políticos, n. ${ }^{9} 101$, págs. 414-422, en concreto, pág. 418.

Por contra, aquí no se sostiene la necesidad expresa del reconocimiento constitucional de cada una de las especialidades militares, lo cual sería impropio de la naturaleza de una Constitución. La consideración institucional de las FAS tal y como aquí se sustenta, implica que, de un lado, no haya una negativa constitucional expresa a la especialidad militar de la que se trate (por ejemplo, que no se niegue la disciplina militar). No es menester que se reconozca expresamente la disciplina militar para que ésta sea admisible constitucionalmente. 


\section{El dualismo sociológico en la percepción de las Fuerzas Armadas y su interconexión con el dualismo jurídico-constitucional. De la normatividad de la ley de leyes al "modelo constitucional» de Fuerzas Armadas}

En la disciplina sociológica ${ }^{37}$ se ha dado, también, un claro dualismo a la hora de concebir a las FAS. Resultan ya clásicos los modelos "institucional" y "ocupacional» de FAS, definidos por Charles Moskos ${ }^{38}$. Con ellos el norteamericano reproducía dos corrientes esenciales en la Sociología militar en razón de la convergencia o divergencia de las FAS con la sociedad ${ }^{39}$, Moskos distinguió la existencia de un modelo «insti-

37 Al respecto véase, entre otros, HaRRIES-JENkINS, Gwyn y Moskos Jr., Charles, Las fuerzas armadas y la sociedad, con introducción de Alonso BAQUER, Miguel, Alianza Editorial, Madrid, 1984, que contiene una reseña comentada de más de 600 títulos sobre la materia.; AA. VV, La institución militar en el Estado Contemporáneo, compilado por Rafael BAÑón, y José A. OLMEDA, Alianza Editorial, Madrid, 1985 y la bibliografía ahí contenida (págs. 326-351). En general, resultan básicas las siguientes obras: Janowitz, Morris, The professional Soldier, The Free Press, 1960, ahora en El soldado profesional, Ministerio de Defensa, Madrid, 1990; Huntington, Samuel P., El soldado y el Estado, (1957), Círculo Militar, Buenos Aires, 1962; Busquets, Julio, El militar de carrera en España, (3.. ed.), Ariel, Barcelona, 1984 y Moskos Jr., Charles y Wood, Frank R. Lo militar: ¿más que una profesión?, Ministerio de Defensa, Madrid, 1991.

38 Cfr. Moskos, Charles C. "La nueva organización militar: ¿institucional, ocupacional o plural?", en AA. VV, La institución militar... cit. págs. 140-152, véanse, especialmente, los diversos trabajos incluidos en Lo militar: ¿más que una profesión?. Ministerio de Defensa, Madrid, 1991 en tanto en cuanto la obras giran especificamente sobre la virtualidad actual de estos parámetros de análisis.

39 A riesgo de una excesiva simplificación, puede entenderse la existencia de dos corrientes esenciales en la sociología militar, en buena medida personalizadas. De un lado, autores como Huntington sostienen que la eficacia militar y su neutralidad política requieren necesariamente un aislamiento de los valores sociales; de ahi que parece adecuado distanciar al colectivo militar de la sociedad civil. Desde esta perspectiva, prima, pues, un punto de vista divergente. Al respecto, ver, HuNTINGTON, Samuel P., El soldado y el Estado... cit.; "La mentalidad militar: el realismo conservador de la ética de los militares profesionales", en AA. VV, La institución militar... cit. págs. 185-207, en la misma obra, ver, "Poder, ideología y profesionalidad: las relaciones civiles-militares en teoría", págs. 235-253.

Por contra, autores como Janowitz se acercan más a una posición convergente, al subrayar la necesidad de que la institución militar converja hacia el resto de la sociedad, aunque, sin verse abrumada por ella. Cfr... JANOWITZ, Morris, El soldado profesional... cit.; "Changing Patterns of Organizational Authority: The Military Establishment", en Military Conflict", Sage, Beverly Hills, 1975, págs. 221-238, (ahora en "Las pautas cambiantes de la autoridad organizativa: la Institución militar", en AA. VV, La institución militar... cit. págs. 81-100); "The Internal Organization of Militar Institutions", en Military Institutions an coercion in the Developing $\mathrm{Na}$ - 
tucional» y un modelo "ocupacional». En el formato llamado «institucional" o "divergente" los ejércitos quedan distanciados de la sociedad y del sistema político "civil», se da una concepción severa de los valores militares, parejo a un reconocimiento mínimo de los derechos y libertad del militar ${ }^{40}$. A diferencia de este modelo institucional, se califica de "ocupacional» o "convergente" a aquél tipo de ejército más integrado en la sociedad civil funcional, social y políticamente ${ }^{41}$. Asimismo,

tions, University of Chicago, 1977, págs. 107-150, (ahora en "La organización interna de la institución militar», en AA. VV, La institución militar... cit. págs. 101-139). Esta obra ya citada gira completamente en torno a estos modelos o formatos organizativos de Ejército.

Como Moskos, Charles C. afirma ("La nueva organización militar..." cit. pág. 142.) "los tres modelos tienen en común una referencia al continuum que va desde una organización militar altamente diferenciada de la sociedad civil hasta un sistema militar fuertemente convergente con las estructuras civiles".

40 El formato llamado institucional vendria a suponer la concepción tradicional del Ejército y relacionada con la habitual percepción generalizada sobre el Ejército de Tierra. De sus diversos caracteres, cabe destacar como pauta genérica la estaticidad o la resistencia natural a los cambios. Resulta una nota particular la mentalidad conservadora como rol de la organización, asimismo, en la formación del militar y en la propia actuación de la institución se exacerban los históricos valores militares y la disciplina militar - no demasiado vinculada a la sumisión al poder político democrático-. En este modelo, se parte de un supuesto nexo e identificación del Ejército con la población, para lo cual el servicio militar es un instrumento necesario; sin embargo, se favorece por diversos métodos la divergencia de la población militar al respecto de la civil. Se entiende que con tal alejamiento de la sociedad se faculta el mejor cumplimiento de las funciones militares, entre las que se encuentra la guarda y custodia de unas esencias patrias, incluso al margen de la voluntad democrática. Entre estos medios alienantes destaca el sistema retributivo establecido en el modelo institucional, basado en una remuneración por debajo de los precios de mercado, si bien compensada por unas retribuciones "en especie» que vienen a suponer unos privilegios al respecto de la consecución de necesidades básicas: vivienda, alimentación, educación, servicios médicos, ocio, etc. El militar vive, compra, o se divierte con militares. De este modo, pese a la relativa austeridad de sus salarios, los militares encuentran reconocimiento por su entrega a la Patria y, lo que es más importante, se fortalece el corporativismo. Pese a cierta autonomía política de la institución así considerada, al militar individual se le somete a una muy estricta disciplina y a un régimen de derechos y libertades más que reducido. Además, en este modelo institucional, el militar lo es las veinticuatro horas del día, independientemente de que esté o no de servicio.

41 El formato denominado ocupacional resulta contrario al anterior; en él destaca básicamente su dinamicidad y adaptabilidad a los cambios registrados por la sociedad y por la técnica militar. Sin obviar la necesidad de la disciplina en el Ejército, para su verdadera efectividad se pretende su actualización en relación con las modernas exigencias, para lo cual, se requiere una flexibilización de la misma. Así, se dota al soldado de una mínima esfera decisoria, que al final revierte positivamente en su actividad. Al mismo tiempo, se aboga por la adopción de los adelan- 
Moskos señaló la existencia de un tercer modelo denominado "plural", que viene a suponer la proyección heterogénea de los dos anteriores en las distintas Armas, Cuerpos o Unidades que componen las FAS ${ }^{42}$.

Pues bien, estos formatos sociológicos institucional / ocupacional guardan evidentes paralelismos con los posicionamientos institucionalistas / administrativistas que en lo jurídico se han dado en España ${ }^{43} . Y$

tos organizativos civiles para muchos ámbitos de la actuación militar, actividad ésta que en virtud de la técnica se aproxima paulatinamente a la civil. Para realizar la función militar ya no resulta imprescindible una acendrada vocación o un alto honor y espiritu; al menos no tanto como lo exigido para prestar cualquier otro servicio a la Administración del Estado. Tanto en el modelo institucional como en el ocupacional, priman la funcionalidad y la eficacia, si bien, en este último, éstas se conciben conforme a las pautas impuestas por la modernidad. Es por ello por lo que no siempre se entiende como positivo el servicio militar obligatorio, por disfuncional; cuanto menos, mediante éste no se pretenden fines "institucionales", como la estructuración nacional de la sociedad. En este modelo, el militar es un funcionario que presta un importante servicio al Estado y a la comunidad, pero para prestarlo basta con que se le considere militar sólo durante las horas de ejercicio de su función; a la Administración no le importa su vida fuera del servicio más allá de lo que pueda afectar directamente al mismo. La retribución se establece conforme a los criterios de mercado 0 , al menos, se remunera homogéneamente con relación al resto de los funcionarios; en consecuencia, desaparecen antiguos privilegios en "especie" que, como se ha mencionado, refuerzan un excesivo corporativismo, ahora entendido como innecesario.

Para realizar mejor las funciones que el poder democrático les asigna, en este modelo no resulta necesaria la separación del colectivo militar del resto de la sociedad, con la que convergen en muchos aspectos. Aún es más, la inserción del militar en la sociedad es una garantía objetiva para evitar que la tenencia de los medios coactivos de la fuerza pueda emplearse autónomamente, en contra la voluntad de la población - como lo fueron en su momento histórico las milicias nacionales-. Dada esta convergencia con la esfera civil, la neutralidad militar se exige de la institución, no de sus miembros individualmente considerados, a los que se les reconoce la mayoría de sus derechos políticos e incluso laborales. Por último, en este modelo ocupacional, la restricción de los derechos y libertades del militar debe ser acorde a la funcionalidad real de la Administración militar, obviándose anacronismos históricos y sociales propios del modelo institucional, que en nada coadyuvan a la verdadera eficacia de la organización.

42 Este modelo plural no es una visión ecléctica de los formatos institucional y ocupacional, sino que se trata de parcelar los diversos sectores del estamento castrense; así, se atribuye a cada parcela los rasgos ocupacionales o institucionales según convenga a la naturaleza de la función a realizar. Resulta, precisamente éste el modelo preferido por este autor (cfr. "La nueva organización militar..." cit. pág. 152.)

43 Dicha relación sólo es advertida expresamente en la obra de RodRíguezVillasante y Paieto, José L., en "La Ley 17/1989, de 19 de julio..." cit. págs. 168-169, si bien subyace con claridad en la obra de Blanouer, David, Ciudadano y soldado... cit. cfr. págs. 233 y ss. 
es que tanto uno como otro dualismos son relativos al grado de adecuación de las FAS a su contexto actual. Así, de manera semejante al dualismo jurídico, pero desde una perspectiva más amplia como corresponde a la Sociología, se da una polarización a la hora de concebir el grado de adecuación de las FAS al contexto cultural, social, político y económico del presente.

La interconexión de lo sociológico y lo jurídico deviene evidente. El modelo sociológico ocupacional quedaría aparentemente emparentado con la concepción administrativista de las de las FAS. El estricto normativismo administrativista impondría la sujeción más estricta de las FAS al.poder democrático, a los principios constitucionales generales y a los derechos y libertades, es decir, al contexto jurídico-político constitucional. En el lado opuesto, en clara coincidencia terminológica, el formato sociológico institucional se avendría bien con la percepción jurídico-institucional de las FAS, que parece excepcionar constitucionalmente la obligación de adaptarse a su contexto jurídico-político. Se trata, pues, de las dos caras de una misma moneda, apreciada desde dos disciplinas diversas: la Sociología y el Derecho. Sin embargo, no hay que fundir y confundir uno y otro plano.

Al jurista no concierne apreciar si se encuentra ante un modelo sociológico institucional u ocupacional ${ }^{44}$, éste no sería un enfoque del todo acertado. Ello es así en tanto en cuanto la Constitución establece su propio modelo de FAS. Este modelo constitucional de FAS no es sino el modo en el que esta institución ha quedado reconocida y conformada por todas las reglas y principios contenidos en la ley de leyes. $Y$ es que la Constitución contiene reglas, principios y valores generales proyectables sobre los elementos que definen los modelos de FAS (finalidad, naturaleza de los ejércitos, concepción de la profesión militar, relaciones con la sociedad civil, posición política de los ejércitos,

44 Podria pensarse que al jurista concierne apreciar la adecuación de uno u otro modelo sociológico al sistema constitucional, es decir, apreciar en qué medida resulta admisible constitucionalmente un modelo sociológico institucional, uno ocupacional e incluso uno plural.Un análisis desde esta perspectiva lo seguí en el citado estudio Cotino Hueso, Lorenzo, "El reto de la profesionalización..." cit. BLANQUER, por su parte, se plantea la cuestión de los modelos sociológicos de Ejército afirmando que el formato institucional es el mayormente acorde con la eficacia exigida a las FAS en virtud del articulo octavo y el formato ocupacional el que respeta la optimización de los derechos y libertades. (Cfr. Blanouer. David, Ciudadano y soldado... cit. págs. 234 y 235). 
etc. $)^{45}$. Como consecuencia, la misión del jurista debe consistir en descubrir cuál es el modelo constitucional (y no sociológico) de FAS. Ahora bien, para emprender esta tarea el jurista requiere, ineludible y previamente, constatar $y$ determinar la premisa de la que parte: la plena normatividad de la Constitución para el ámbito militar. Si la Constitución contiene normas generales definitorias de un modelo de FAS -el constitucional-, es preciso aseverar la aplicación de la norma suprema sobre este ámbito. $Y$ esta labor, como se verá, no exenta de dificultades, es la que aquí pretende operarse, una vez sentadas las anteriores premisas.

\section{Una advertencia previa}

A pesar de los evidentes nexos que se han apreciado entre las perspectivas sociológica y jurídica ( $y$, por ende, los paralelismos entre el modelo sociológico "institucional» de FAS y la categorización juridico "institucional» de las mismas), el tratamiento debe ser diferenciado. De ahi que quepa advertir que, salvo mención expresa en contrario, el empleo que se dé a continuación del término «institucional» responde al enfoque jurídico del mismo.

\section{RECHAZO DE UNAS "CONNOTACIONES INSTITUCIONALISTAS QUE MERMASEN LA NORMATIVIDAD CONSTITUCIONAL"}

\section{Cómo abordar la materia de forma adecuada}

Para sostener la completa recepción del principio de supremacía constitucional ( $y$, por ende, también el de subordinación militar) en

45 Para apreciar un esquema bastante completo de los elementos que definen un modelo de Ejército, puede verse, FLECKENSTEIN, Bernhard, "Alemania Federal", en la obra colectiva dirigida por Moskos, Charles C., Lo militar: ¿más que una profesión?, cit., págs. 232-253, en concreto en la pág. 235. Así, a la hora de determinar ante qué modelo de ejército nos encontramos se trata de escrutar cómo se determinan en la Constitución, al menos en sus aspectos básicos, los elementos determinantes y definitorios del modelo de FAS: funciones, elementos integrantes, la sujeción a los poderes democráticos del Estado, el estatuto de sus miembros, la admisibilidad constitucional de la disciplina $y$ del espíritu militares tradicionales, las exigencias contenidas en la ley de leyes respecto de la composición social de las FAS, la naturaleza de la jurisdicción militar, etc. Averiguando la configuración constitucional de tales queda perfilado cuál es el modelo constitucional de FAS. 
nuestra Constitución en absoluto es menester negar la virtualidad de las teorias generales institucionalistas ${ }^{46}$, ni incluso hace falta negar que las FAS son una institución ${ }^{47}$. $Y$ es que devendría poco riguroso $-y$ ciertamente paradójico- que una "connotación institucionalista" ${ }^{48}$ deba rechazarse para el ámbito militar (porque parece comportar una serie de vicios para los propios contenidos constitucionales) y por contra, deba admitirse en materia de derechos fundamentales (pues supone un formidable elemento de determinación de su alcance $)^{49}$. Del mis-

46 A mi juicio, negar las concepciones institucionales del Derecho comporta un grave riesgo. No puede descartarse y renunciar a una percepción general del Derecho a los solos efectos de intentar evitar sus negativos efectos en el ámbito militar.

No obstante, éste es el camino seguido por, LOPEz RAMÓN, Fernando, La caracterización jurídica... en especial, págs. 368-369, donde intenta rechazar las corrientes institucionalistas generales. Por su parte, Dominguez-Berrueta, Miguel, y otros, en "El control jurídico-constitucional de la transición militar..." cit., págs. 2955-3006, persigue a lo largo de su trabajo "negar las connotaciones institucionalistas" (cfr. ob. cit. 2990), si bien, al final del mismo parece rendirse a la virtualidad del carácter institucional de las FAS y a los efectos que ello conlleva (cfr. ob. cit. 3001-3002).

47 Tampoco se trata de mantener que las FAS no cumplen los rasgos conceptuales de ser una institución. Esta vía, cuanto menos, no comporta el grave riesgo de negar las concepciones institucionales del Derecho. Ésta es la línea elegida, básicamente, por BARCELONA LLOP, Javier, "La organización militar..." cit. que dedica buena parte de su estudio a negar que las FAS reúnan los caracteres definitorios de una institución.

48 Dominguez-Berrueta, Miguel y otros, «El control jurídico-constitucional..." cit., pág. 2990 afirma que "rechazando la connotación institucionalista, se llega más fácilmente a la idea de "vinculación positiva" a la Constitución".

49 Al respecto de la oportunidad de combinar un análisis estructural-formal con uno institucional-funcional en el ámbito de los derechos fundamentales puede verse Freixes SANJUÁN, Teresa, Constitución y Derechos Fundamentales. Estructura juridica y función constitucional de los derechos. Introducción al sistema de derechos de la Constitución española de 1978, PPU, Barcelona, 1992 (entre otras, ver, págs. 115-119)

La proyección institucional que ahora se significa como positiva respecto de los derechos fundamentales se relaciona intimamente con la necesidad de delimitar el contenido constitucionalmente protegido de éstos. Al respecto, en especial, véase Martín Retortillo, Lorenzo y De OtTo Pardo, Ignacio, Derechos fundamentales y Constitución, Civitas, Madrid, 1988, en concreto, la segunda parte del libro, debida al segundo de los autores, y en particular, entre otras, págs. 142, y 151-152. La jurisprudencia constitucional, tal y como SánCHEz FerRIz, Remedio, ha percibido (cfr., entre otros, "Comentarios a la jurisprudencia del Tribunal Constitucional. Un año en la jurisprudencia constitucional sobre la información. ¿Consolidación o cambio de la doctrina anterior?", en RGD, mayo de 1994, págs. 5033-5051), asumió en buenat medida esta aportación del maestro de Oviedo (cfr. sentencias. 15/1993, 282/1993 y 336/1993). 
mo modo, sostener una concepción administrativista de las FAS que supusiese negar que tras lo que ha sido constitucionalizado como Administración militar subyace una verdadera institución histórica, sociológica jurídica devendría, por necesidad, endeble. Por ello entiendo que la forma correcta de abordar la cuestión de una manera rigurosa consiste en apreciar la verdadera significación actual y alcance constitucional de las corrientes institucionalistas del Derecho $y$, por ende, deducir las consecuencias jurídicas que comporta el hecho de reconocer que las FAS son una institución.

De este modo, a continuación se pretende demostrar que el hecho de que las FAS sean una institución no puede comportar cualquier menoscabo - o autoderogación- de la normatividad de la Constitución española. Más tarde, una vez superadas estas "connotaciones institucionalistas", se sustentará la plena normatividad constitucional desde una perspectiva diferente, la estructural-formal.

\section{La inicial significación de las teorías institucionalistas} supondría cierta merma de la normatividad constitucional sobre lo militar

A) La perspectiva institucional clásica y la sujeción de la institución militar al Derecho

Desde principios del presente siglo, y con directos precedentes en el anterior, ante la visión formalista, normativa y estatalista asentada magistralmente tanto por Kelsen como por la Escuela de Derecho público alemán (Gerber, Laband, etc.) surgieron diversas reacciones desde ámbitos diversos. En Italia con Santi Romano o en Francia con Hauriou, como reacción a un aséptico formalismo, para acercar la realidad al Derecho surgiría una teoría entonces llamada institucional ${ }^{50}$. En Alemania Schmitt, afirmaria la preexistencia de un "orden interno" que

50 Así, Martín Retortillo, Sebastián, en "La doctrina del ordenamiento juridico de Santi Romano y algunas de sus aplicaciones en el campo del derecho administrativo", estudio preliminar a la obra Romano, Santi, El ordenamiento jurídico, IEP, Madrid, 1963, págs. 9-77, presenta al institucionalismo como una respuesta del pluralismo jurídico contra la concepción monista que reduce el Derecho al único derecho estatal, de otro lado, sitúa al institucionalismo contra el positivismo juridico en su concepción más estricta.

Como recuerda Boв8ı, Norberto, Contribución a la Teoría del Derecho. Fernando Torres Editor, Valencia, 1980 pág. 156 y en Teoría General del Derecho, De- 
repugnaba toda regulación y el necesario acercamiento del Derecho a la realidad de dicho orden ${ }^{51}$, algo tan contrario al formalismo de Kelsen, Triepel, también en aquel país insistiria en el acercamiento a la realidad y en el funcionalismo ${ }^{52}$. Bien merece la pena resaltar algunos elementos básicos de esta corriente, en sus postulados iniciales, pues

bate, Madrid, 1991, pág. 22, los postulados institucionalistas adquieren su máxima representación con Hauriou y Santi Romano. Sin perjuicio de ello, la perspectiva institucional del Derecho adquiere diversas proyecciones como la tradición cristiana (tal es el caso de Georges Renard, Theorie de l'institution, París, 1930), o la influencia de corrientes socialistas libertarias (Proudhom), o anárquicas, o sindicalistas (Gurvitch). Como destaca Bobbio, la concepción de Santi Romano, que es la que ha la postre ha perdurado permaneció al margen de la extensión de estas teorías por parte de Gurvitch o Renard.

Resulta menester realizar una advertencia, pese a que generalmente se cite conjuntamente a Hauriou y a Santi Romano, hay que advertir que ni sus construcciones ni sus intenciones eran las mismas (ver, Boввіо, Norberto, Contribución a la Teoria del Derecho... cit., págs. 161-165). Cabe afirmar, con cautelas, que Santi Romano supo encauzar jurídicamente la inquietud sociopolítica del de Burdeos.

51 En especial puede seguirse su antiformalismo en Sснмгтт Carl, Sobre los tres modos de pensar en la ciencia jurídica, cit. El alemán partiría de que el Derecho queda determinado primariamente por un orden interno, no por reglas decisiones. Dicho orden significaba un resultado de principios morales y racionales, configurados en las costumbres, con sentimientos, condicionamientos del entorno y a partir del hecho de que el hombre no puede vivir más que con otros hombres. La regla no crea orden, sino que regula la orden (pág. 12). La conexión de este orden interno con las percepciones institucionalistas era evidente, así, en las págs. 20-21 afirmaría "el orden interno concreto, disciplina y gloria de toda institución repugna cualquier intento de normalización y regulación total», la norma no podía desconocer la institución. "Si se separa el pensamiento jurídico de todo contenido y de la situación normal que está en su base, entonces se produce un distanciamiento cada vez mayor de todo contenido" (pág. 43). En las págs. 59 y ss. manifiesta su aprobación de las corrientes de Hauriou y Santi Romano, diciendo que con ello se superaba el normativismo. Pero, no obstante, advertía que el concepto de "institución" no se adaptaba al contexto dogmático alemán.

52 TrIePEL, Heinrich, Derecho público y política, cit. reconoceria que cuando el jurista complementa su construcción lógico-formal de los conceptos con consideraciones sociales, históricas, éticas o de otro tipo "no hace Derecho sino Sociología", ahora bien, arrojar fuera del Derecho todo lo que no sea lógico formal supone "un empobrecimiento de nuestra ciencia». "El purismo lógico, que excluye al Derecho del contacto con otras ciencias, que hace de él una esotérica teoria solo comprensible para los iniciados, que presenta todas las instituciones estatales [...] como esquemas sin sangre sin referencia alguna a su contenido ético, debe conducir necesariamente a una esterilización de la teoría del Estado y del Derecho" "Uno no puede llegar de ningún modo a un conocimiento de las normas jurídicas sin formarse una idea de las relaciones finalista de las que trata lo juridicon (ob. cit. págs. 49-53). 
los mismos conducen en alguna medida a una cierta merma de la normatividad respecto de las instituciones, como pueda serlo la militar. Siguiendo una construcción institucional -digámoslo asi- clásica parece que se mantenga una independencia de la institución (en nuestro caso la militar) del contexto normativo que la regula.

La corriente institucional ${ }^{53}$ niega que la norma aislada sea el elemento primario de la experiencia jurídica; del normativismo formalista kelseniano se debía dar paso al reconocimiento de unos principios institucionales, reglas no escritas que derivaban de la propia la naturaleza de las llamadas «instituciones» o formas típicas y básicas de una rama del Derecho ${ }^{54}$. Se considera que la «institución" ("ordenamiento" u "organización»" ${ }^{5}$ ) es la que hace nacer al Derecho; aún es más, la organización es Derecho, en el sentido de ordenamiento, no en el de normas aisladas; el ordenamiento asume y conserva los elementos del grupo social ${ }^{56}$.

53 Las siguientes notas de la teoría de la institución son extraídas de RomaNo, Santi, El ordenamiento jurídico... cit., en especial, págs. 330 y ss., y MARTin RETORTILLO, Sebastián, en "La doctrina del ordenamiento jurídico..." cit.; HaURIOU, Maurice, "La teoría de la institución y la fundación", en Obra escogida, Instituto de Estudios Administrativos, Madrid, 1976, págs. 256 y ss.; BosBio, Norberto, Contribución a la Teoría del Derecho... cit., págs. 156 y ss., 189 y ss. y 253 y ss., también, su Teoria General del Derecho... cit., págs. 18 y ss. 164 y ss.; Carretero Pérez, Adolfo, "Concepto constitucional de fuentes del Derecho", en AA. W., La Constitución Española y las Fuentes del Derecho. (Vol. l), págs. 392 y ss.; Pérez Moreno, Alfonso, "El concepto de ordenamiento jurídico en la Constitución", en AA. VV., La Constitución Española... cit., págs. 1633 y ss. y García de Enterría, Eduardo, y Fernández Rodriguez, Tomás, Curso de Derecho Administrativo, Tomo I, (3." ed.), Madrid, 1983, págs. 53 y ss.

54 Así, Carretero Pérez, Adolfo, "Concepto constitucional..." cit., pág. 391 considera que "las instituciones son parte del Derecho Positivo vigente y se deducen de él sin necesidad de ley que las exprese, por ser fuentes legales, ya que las leyes enuncian implicitamente estos principios, a los cuales se les denomina también inmanentes a la naturaleza de las instituciones". En el mismo sentido, véase Pérez MoRENo, Alfonso, "El concepto de ordenamiento jurídico en la Constitución», en AA. VV., La Constitución Española y las Fuentes del Derecho... cit., (Vol. 3), pág. 1639.

55 Al respecto del empleo equivalente de los términos "institución", "ordenamiento", "organización" cfr. Romano, Santi, El ordenamiento jurídico... cit. págs. 128-132. Como más tarde se señala, la confusión de estos conceptos resulta uno de los mayores problemas de indefinición de las corrientes institucionalistas. En este sentido cobra relevancia el término de uinstitución jurídica» consagrado por Hauriou, como realidad social que, reuniendo determinados elementos, pasa a la categoría de afirmación legal, llegando de esta suerte lo sociológico a convertirse en jurídico, así en Hauriou, Maurice, "La teoría de la institución..." cit. págs. 257 y ss.

56 Asi lo entiende Carretero Pérez, Adolfo, "Concepto constitucional..." cit., pág. 392. 
Esta identificación del ordenamiento con la organización (en nuestro caso, el ordenamiento militar con la institución castrense), mengua de algún modo la capacidad del Derecho de desvincularse de la idea de la propia institución, de su propia naturaleza y estructura (es decir, dificulta la capacidad de las normas militares de desvincularse de los caracteres propios de los ejércitos). Para las corrientes institucionalistas, la institución precede a la norma y la define previamente como "fuente de Derecho". El ordenamiento no es un conjunto racionalizado de preceptos abstractos (formalismo jurídico-estructuralista) sino que, por contra, tales preceptos adquieren su verdadera virtualidad en el marco de la institución que tiene existencia previa. Como concluye García Pelayo, para el institucionalismo no es el Derecho el que crea la institución, sólo sirve a la cohesión de ésta ${ }^{57}$; en consecuencia, el Derecho militar únicamente da cohesión a la institución de las FAS.

Como se ha afirmado, tal concepción institucional clásica implica una minusvaloración del alcance normativo; el Derecho simplemente cohesiona la realidad previa institucional, los caracteres previos de la institución parecen situarse por encima de la norma jurídica. El institucionalismo clásico tiene una clara significación de permanencia, de continuidad y de lo real ${ }^{58}$. Por lo que centra el interés del estudio, desde esta perspectiva clásica, el Derecho sólo conformaría la realidad institucional militar, ésta no sería otra que la determinada por la naturaleza, por la tradición e historia de la institución castrense.

\section{B) La perspectiva ordinamental clásica ya apuntaba la vinculación a la Constitución}

La concepción institucional que se ha apreciado, ya en sus postulados iniciales, se extendió e interrelacionó con una concepción pluralista de las fuentes del Derecho ${ }^{59}$; en virtud de la misma el valor

57 Así citado por LóPEZ-GarRIDo, Diego, "La posición constitucional..." cit., pág. 957 como una de las notas que caracterizan una institución, extraidas del seminario impartido por Garcia-Pelayo en el Centro de Estudios Constitucionales (1983) sobre el tema "El Estado de partidos".

58 Cfr... HaURiou, Maurice, "La teoria de la institución y la fundación", cit. pág. 259.

59 Pese a su interrelación, es necesario distinguir la teoría de la institución de la teoria de la pluralidad de los ordenamientos jurídicos, éstas no son un todo unitario. (Respecto de la necesaria distinción de estas teorias, véase MARTin RetorTI- 
supremo de la Constitución quedó reforzado. Se configuró así el principio ubi societas ibi ius, donde quiera que se dé una realidad social institucional, necesariamente habrá un ordenamiento. En consecuencia, se afirmó la existencia de una diversidad de ordenamientos jurídicos emanados (formal o materialmente) de los diversos centros de poder de carácter sociológico, de las distintas instituciones ${ }^{60}$.

El reconocimiento de un sistema formado por una pluralidad de ordenamientos comportaba la necesidad de reconocer la existencia de relaciones de coordinación y subordinación entre dichos ordenamientos. La unidad de dicho sistema se lograba por la existencia de unos principios estructurales y materiales (las normas cambian pero el ordenamiento jurídico permanece en tanto que permanecen sus principios $^{61}$ ). Tales principios quedaban recogidos en la norma básica del sistema, la Constitución. Como consecuencia de todo ello, la ley de leyes pasaba a considerarse el instrumento fundamental en favor de la unidad y coherencia del ordenamiento jurídico.

Parece oportuno destacar no sólo la sujeción a la norma de normas, sino la centralidad que para la teoría institucionalista adquieren los valores y principios en ella incluidos. Así, cabe ya subrayar que en la teoría institucional la ley de leyes es la regla o norma fundamental que ordena la institución, que es el Estado y, por lo tanto la Constitución es el ordenamiento superior, al que se subordinan todas las demás reglas, que son ordenamientos dependientes de aquép2.

Hasta el momento, han sido descritas las líneas básicas que definían clásicamente la concepción institucionalista u ordinamental del Derecho y su significación respecto del ámbito militar. Se trataría, pues, de reconocer la existencia de la institución militar que determinaría la existencia de un ordenamiento propio, el Derecho militar, regido por unos principios propios adecuados para la organización militar. Es preciso ahora concretar el alcance que tienen estas iniciales formu-

LLo, Sebastián, en "La doctrina del ordenamiento juridico..." cit. págs. $45-49$, en igual sentido, véase Bоввіо, Norberto, Contribución a la Teoría del Derecho... cit. pág. 158 y ss.)

60 Las connotaciones políticas de estas teorías pluralistas eran obvias, frente al monismo estatalista en un periodo dominante de los totalitarismos. Ello era así en especial en Hauriou; recuérdese que su trabajo traía consigo el subtítulo de "Ensayo de vitalismo social»).

61 Cfr... Garcia de Enterría, Eduardo, y Fernández Rodriguez, Tomás, Curso de Derecho Administrativo, cit. pág. 55. cit., pág. 392.

62 En este sentido, Carretero Pérez, Adolfo, "Concepto constitucional..." 
laciones institucionales en la actualidad $y$, concretamente en nuestro sistema constitucional. Es así como se apreciará la verdadera virtualidad jurídica que pueden alcanzar las nociones de "institución". y "ordenamiento" militar.

\section{La evolución y significación actual de las teorías institucionalistas: la plena sumisión de las instituciones y los ordenamientos al Derecho y en concreto a la Constitución}

Parece coincidirse en que la teoría de la institución, en su elaboración inicial, resultaba compleja y confusa, no refinada y falta de precisiones $^{63}$. No obstante, a pesar de sus posibles deficiencias o insu-

63 En esta dirección crítica con la concepción institucional clásica, ver, BosBı, Norberto, Contribución a la Teoría del Derecho... cit., pág. 161 y ss. El mal uso del concepto de «institución", originado por la propia indefinición del mismo, asi como la inutilidad de su empleo han sido las críticas vertidas al respecto de los iniciales postulados institucionalistas. MARTin RETORTILLo, Sebastián, en "La doctrina del ordenamiento jurídico..." cit. pág. 13 no duda en afirmar que los discípulos de Hauriou pretendian encontrar instituciones en todas partes, y los de Romano, ordenamientos jurídicos. Carretero Pérez, Adolfo, "Concepto constitucional...", cit., pág. 392 afirma que si el Derecho nace del hombre y de la sociedad, admitir que nace de una «institución» no es suficientemente esclarecedor, y quizá resulta superfluo, del mismo modo critica el uso que se ha hecho de este concepto tan indeterminado. GIANNINI, Massimo Severo, Derecho Administrativo, (traducido por Luis Ortega), Vol. I, Ministerio para las Administraciones Públicas, Madrid, 1992, pág. 162 considera que mediante el concepto de "institución» se ha pasado a pretender explicar fenómenos que podrian haberse desenvuelto de otro modo distinto, sin tener que recurir a la teoría de los ordenamientos.

Asimismo, también se aduce en contra del institucionalismo que ha quedado fuera del contexto el contenido político antiestatalista que en sus inicios tenía la teoría pluralista. Por lo cual, en la actualidad CASSESE, Sabino, "Instituzione: un concetto ormai inutile", en Politica del Diritto, n. 1-2, 1979, págs. 53-62 ha calificado su empleo de "inútil» (citado en LóPEz Ramón, Fernando, La caracterización jurídica..., cit., pág. 367.)

Dentro del ámbito doctrinal concreto de las FAS, diversos autores han criticado la indeterminación del concepto de institución y el mal uso del mismo. Así, LóPEZ-GARRIDO, Diego, "La posición constitucional...", cit., pág. 957, afirma que "el concepto [de institución] se hace complejo y polivalente; y no se sabe bien qué significa; en igual sentido BARCELONA LlOP, Javier, "La organización militar...", cit. pág. 60 y López RAmón, Fernando, La caracterización jurídica..., cit., págs. 367 y ss. También, se ha puesto de manifiesto su irrelevancia jurídica, asi SuÁrez Pertierra, Gustavo, "Regulación jurídico-constitucional de las Fuerzas Armadas", cit. afirma en la pág. 2377 que "el concepto de institución resulte inocuo, toda vez que no implica, sin más, autonomía organizativa y capacidad de decisión". 
ficiencias, no se puede negar que la concepción institucionalista suponía innegables avances respecto del estructuralismo formalista, que alejaba al Derecho de la realidad. Por ello, algunos autores como Bobbio se encargaron de llevar a cabo una importante crítica positiva de la consideración institucional del Derecho ${ }^{64}$. Tras la redefinición que se ha llevado a cabo de esta concepción jurídica, se han superado algunas de sus deficiencias y omitido algunas de sus facetas oscuras. Como consecuencia, el institucionalismo parece propiciar una constructiva superación del positivismo jurídico y sus excesos formalistas. Tal y como apunta Freixes, hoy día el institucionalismo sigue siendo necesario y compatible con el formalismo jurídico $0^{65}$.

Sin embargo, dejar atrás antiguas insuficiencias y alcanzar la validez actual de las construcciones institucionalistas ha supuesto un coste respecto de los iniciales postulados. Con la "redefinición" habida, los conceptos iniciales de "ordenamiento", "organización" $y$, especialmente, el de "institución" han quedado relativizados; las instituciones han quedado a expensas del Derecho positivo.

\section{A) El nuevo significado y alcance jurídico de la noción "institución"}

En razón de los reajustes efectuados por la doctrina, los principios y fines de la institución u organización vienen total o parcialmen-

64 El mayor esfuerzo se debe a BosBio, Norberto, Teoría General del Derecho... cit., págs. 22 y ss. Dicho autor viene a conciliar a la institución con el Derecho, pues afirma que es preciso que el Derecho determine previamente los fines de la organización $y$, cuanto menos, los principios para lograr aquéllos. Estas determinaciones, a decir de Bobbio, sólo pueden realizarse a través de reglas; la dotación de estas reglas se realiza previa o conjuntamente con el proceso de institucionalización. Como consecuencia de estas consideraciones, la teoría normativa sale reforzada con la institución, "pues es siempre la producción de reglas el fenómeno originario, aunque no exclusivo, para la constitución de una institución". (cfr. pág. 23.)

65 Cfr. Freixes SAnjuÁn, Teresa, Constitución y Derechos Fundamentales... cit., en las págs. 6-7 afirma que:

"el Derecho precisa, pues, de una interpretación ajustada a su propia esencia $y$, al mismo tiempo, a la función que desarrolla como tal. [...] No existe, en consecuencia, una contradicción insalvable entre estructuralismo y análisis funcional. Si el estructuralismo nos aporta una base científico-positiva, el análisis funcional la complementa con una interacción mutua que nos acerca al conocimiento completo de los fenómenos jurídicos. [...] Esta complementariedad existente entre estructuralismo $y$ análisis funcional se revela sumamente importante en el estudio del Derecho Constitucional". 
te determinados por la norma jurídica ${ }^{66}$. La institución ya no es Derecho, sino que la existencia de ésta depende en buena medida de las propias normas jurídicas. En consecuencia, el "precio" de la admisibilidad del institucionalismo moderno ha sido el de quedar a expensas de lo que las normas jurídicas expresan. De acuerdo con la reformulación institucionalista elaborada por Bobbio, estos hechos relativos e inherentes a la organización -que antaño se consideraban Derecho en sí- ya no son ajenos al Derecho positivo, sino que se, fundan total o parcialmente en la propia norma jurídica. Para las FAS y el Derecho militar, el Derecho reconoce, constituye y conforma a la organización militar. Así pues, la naturaleza y realidad sobre las que se funda el ordenamiento jurídico-militar están en muy buena medida determinadas por el Derecho y en primer orden, por la Constitución. En la Constitución están los "dos pies" en los que se mueven las FAS y el Derecho militar, tanto las necesidades de la defensa (la eficacia, disciplina, jerarquía, etc.), como las reglas y principios que ubican a las FAS en el Estado constitucional.

\section{B) La relativización del alcance de los "ordenamientos"}

El indiscutible monopolio estatalista del reconocimiento de las fuentes del Derecho implica negar que existan verdaderos "ordenamientos internos", emanados de fuentes autónomas de poder. De ahí que, actualmente, no puede sostenerse que es de la organización (la militar en nuestro caso) de la que necesariamente emanan las normas jurídicas (ordenamiento interno) ${ }^{67}$. Cuestión diferente es afirmar que estas normas jurídicas (ordenamiento militar) se fundan sobre

66 Véase lo afirmado supra en la anterior nota a pie $n . .54$. Al respecto, afirma Giannini que puede haber normación sin organización, pero no puede haber organización sin normación, es decir, la posición del Derecho resulta insustituible en el ámbito de las instituciones, y no al contrario. Este autor, en un trabajo más reciente ha mantenido esta línea de relativización del significado del ordenamiento jurídico relativo a una organización. Así, cfr. GIANnINI, Massimo Severo, Derecho Administrativo, cit. pág. 162.

67 GIANNINI, Massimo Severo, Derecho Administrativo... cit. págs. 180-181 afirma que pese a que históricamente la organización militar gozara de una autonomía en la emanación de las normas que regulaban la organización, el tiempo ha atenuado poco a poco el rigor de los ordenamientos militares y también en éstos se ha producido una continua invasión de normas del Estado que han acabado por regular directamente amplios sectores cuya competencia venia siendo de normas militares internas. 
hechos relativos e inherentes a la organización militar que regulan, mas no es de la institución castrense de la que emanan estas nor$\operatorname{mas}^{68}$.

De mantenerse la categoría de "ordenamientos", en una versión actual, se trataría de ordenamientos organizativos. Por el mero hecho de reconocerse la existencia de una organización como las FAS (sin capacidad de producción de Derecho), se reconoce la existencia de un "ordenamiento". En consecuencia, la existencia de un ordenamiento militar viene definida por la existencia de una organización, las FAS, reconocidas, constituidas y conformadas a partir de la Constitución, en la que se incluyen toda una serie de reglas y principios que han de regir ${ }^{69}$. Así, es posible coincidir con Giannini cuando afirma que se ha dado "sustancialmente el abandono del concepto según el cual las FAS constituirian un ordenamiento jurídico separado, con propias leyes internas y propia autonomía, y el relacionar e inscribir la Administración Militar en el círculo de la normativa común» ${ }^{70}$.

\section{C) La concepciones institucionalistas actuales conllevan la plena sujeción de la institución de las Fuerzas Armadas y del Derecho militar a la Constitución y el Derecho}

Tal y como se ha señalado, el deficiente institucionalismo inicial quedó superado a cambio de un refuerzo de la vinculación de las instituciones a las normas juridicas. De este modo, las construcciones institucionales han dejado de ser un argumento válido - si alguna vez lo fueron-para eludir la sujeción de las instituciones - tal la militar-a las normas (en especial a la Constitución).

68 Siguiendo a Giannini, bien cabe hablar de "ordenamientos de los cuerpos organizados" y los "ordenamientos sectoriales, cfr. GIANNINI, Massimo Severo, Derecho Administrativo... cit., pág. 179.

69 Entre Is estudios que abordan los perfiles y naturaleza del Derecho militar, destaca sobremanera TiBuRcio Gomes Carneiro, Mário, "Los elementos fundamentales del Derecho militar (Concepto, contenido, codificación, enseñanza)", en Revista Española de Derecho Militar n. ${ }^{9} 12$, julio-diciembre de 1961, págs. 181-206. Ver también, Querol y DuRÁn, Fernando de, Principios de Derecho militar español con arreglo al Código de Justicia Militar de 17 de julio de 1945. Tomo l: Preliminares y Derecho orgánico judicial militar. Tomo Il: Derecho Penal Militar, Editorial Naval, Madrid, 1948 y Rodriguez Devesa, José M. y Serrano Gómez, Alfonso, Derecho Penal Español, Parte Especial (vol. 2), cit. págs. 1283-1284.

70 Cita de GianniNI, M. S., "l Publlici Poterir negli Stati Pluriclasi", en RTDP, núms. 2-3, 1979, págs. 389 y ss. 
Como consecuencia de la actual significación de las corrientes institucionalistas, la naturaleza o la tradición de la institución castrense no determinan "per se" el contenido del ordenamiento militar. El Derecho castrense antes que prefigurado por la naturaleza o historia de lo militar queda, en primer lugar, a expensas de los mandatos, principios $y$ valores reconocidos por la Constitución. La naturaleza y la tradición de la institución militar sólo contribuyen a perfilar el contenido del Derecho militar dentro del espacio que confiere la ley de leyes. La institución queda a expensas de la Constitución. Como contrapartida a esta sumisión a lo expresado normativamente, hoy la concepción institucional ha pasado a constituir un apoyo insustituible que complementa la norma jurídica expresada formalmente y la acerca a la realidad social.

Adentrándonos ya en el terreno de la norma suprema y una vez advertido el desarrollo doctrinal de estas teorías, parece oportuno señalar -aun brevemente- la recepción de estas corrientes institucionales y ordinamentales en la Constitución española de 1978. En particular, resulta interesante detenerse en la determinación del alcance del institucionalismo por parte de nuestro Tribunal Constitucional.

\section{El sentido y alcance de las instituciones y los ordenamientos en el concreto marco constitucional español}

A) La recepción constitucional española del institucionalismo y su significación positiva respecto de la normatividad constitucional

Para la tradición normativa española, las corrientes institucionalistas y ordinamentales de Santi Romano tuvieron su recepción por medio del art. 83 de la Ley reguladora de la Jurisdicción Contencioso Administrativa de 1956 y, años más tarde, en la.reforma del artículo primero del Código Civil de 19747". No fueron pocos quienes al poco de

71 Así es, el art. 83 de la primera ley citada preceptuaba que se estimaria un recurso si el acto o disposición recurridos infringiesen el "ordenamiento juridico». El Preámbulo de aquel texto no dejaba lugar a dudas, respecto de tal conformidad afirmaba «que reconducirla simplemente a las leyes equivale a incurrir en un positivismo superado y olvidar que lo jurídico no se encierra y circunscribe a las disposiciones escritas, sino que se extiende a los principios y a la normatividad inmanente en la naturaleza de las instituciones». El art. 1.4 del actual Código Civil, resulta también expresivo "Los principios generales del Derecho se aplicarán en defecto de ley o costumbre, sin perjuicio de su carácter informador del Ordenamiento juridicon. 
aprobarse la Constitución ya afirmaron la recepción constitucional de los postulados ordinamentistas ${ }^{72}$. Para argumentar tal recepción, bastaría con afirmar las diversas referencias expresas a los ordenamientos e instituciones que se verifican en la Constitución (arts. 1.1, 8.2, 9.1, 86.1, 96.1, 147.1 $\mathrm{CE})^{73}$. Desde la perspectiva propiamente pluralista de las posiciones ordinamentistas, es decir, la que hace referencia a la existencia de una diversidad de centros de emanación del Derecho, hay que convenir con Pérez Luño que nuestra Constitución sólo permite parcialmente la existencia de esta concepción horizontal de los ordenamientos jurídicos, que en modo alguno lesiona la primacia constituciona ${ }^{74}$. De otra parte, la recepción constitucional del institucionalismo se ha sostenido fundamentalmente por la trascendencia que se confiere en el texto a los principios jurídicos ${ }^{75} \mathrm{y}$, singularmente a los valores enunciados en el art. 1.176.

Precisamente este dato se suma a los argumentos que llevan a reforzar la normatividad de la Constitución desde una perspectiva institucional. La propia centralidad que se confiere desde los presupuestos institucionalistas a los valores y principios y el expreso reconocimiento de estos valores y principios en nuestra ley de leyes subrayan la ineludible vinculación constitucional. Es por ello por lo que no pare-

72 Así, cabe citar, entre otros, los trabajos de Carretero Pérez, Adolfo, "Concepto constitucional...", cit.; Diez Picazo, Luis, "Constitución y...", cit.; y Pérez MoreNo, Alfonso, "El concepto de ordenamiento juridico...", cit.

73 Así, en el art. 1.1, en referencia a los valores superiores del ordenamiento; en el art. 8.2 en el que se encomienda la defensa del ordenamiento constitucional; en el art. 9.1, donde se establece la vinculación de la Constitución $y$ del resto del ordenamiento juridico; art. 86.1, en el que se limita la afectación de los Decretos-ley al ordenamiento de las instituciones básicas del Estado; art. 96.1, por el que los tratados internacionales válidamente celebrados pasan a integrarse en el ordenamiento español y, por último, el art. 147.1 en el que se configuran los Estatutos de autonomía como norma institucional básica que el Estado reconoce como integrante de su ordenamiento jurídico.

${ }_{74}$ Pérez LuÑo, Antonio, Los Derechos Fundamentales. Tecnos, 3. edición, Madrid 1988, págs. 155 y ss. considera que el monopolio de fuentes del Derecho por parte del Estado resulta asegurado por la Constitución, y la validez normativa de otras fuentes del Derecho sólo se da en tanto en cuanto la norma constitucional lo permita y reconozca (como el caso de los ordenamientos autonómicos, la autonomía de la voluntad, universitaria o municipal).

75 Básicamente, así, Garcia de Enterria, Eduardo, y Fernandez Rodriguez, Tomás, Curso de Derecho Administrativo, cit., pág. 57.

76 En esta dirección, Carretero Pérez, Adolfo, "Concepto constitucional..." cit., págs. 393 y ss. y Pérez MoReno, Alfonso, "El concepto de ordenamiento jurídico..." cit. págs. 1636 y 1637. 
ce admisible que mediante un punto de partida institucionalista u ordinamentista se pretendiera que tanto la institución castrense como el ordenamiento militar desconociesen la importancia de los ineludibles valores y principios constitucionales.

\section{B) La sujeción de las instituciones a la ley de leyes y el Tribunal Constitucional}

Tal y como se ha señalado desde un inicio, la importancia concreta que aquí se confería al hecho de que se considere a las FAS como una institución era que, de alguna manera, ello implicase cierta inmunización al alcance normativo de la Constitución y del ordenamiento general.

Como se advirtió, aquí no se iba a negar el carácter institucional de las FAS, sino la desviada significación que ello parecía comportar. Hasta el momento, mediante el seguimiento de la evolución de la concepción institucional del Derecho y su recepción en España se puede inferir ya que no cabe una consideración institucional que permita una exclusión de lo expresamente preceptuado por las normas jurídicas. No obstante, la atención a la jurisprudencia constitucional permite dar algún paso más a la hora de concretar el alcance que tiene considerar a las FAS como una institución en sentido jurídico.

Ha sido el propio Tribunal Constitucional quien ha expresado la necesidad de que las instituciones - previas o no a la Constitución- se sujeten plenamente a lo dispuesto por la ley de leyes. Incluso entre su doctrina más controvertida ${ }^{77}$, se desprende que una institución es

77 Se hace ahora referencia a la polémica sentencia 126/1997, de 3 de julio. En la misma el Tribunal ha admitido la preferencia del varón frente a la mujer en la sucesión de los Títulos nobiliarios, ello supone excepcionar el valor, principio y derecho de igualdad (arts. 1.1, 9.2 y $14 \mathrm{CE}$ ) para la institución nobiliaria. No obstante, pese a lo censurable de la sentencia (cuya crítica se recoge en los dos votos particulares formulados por tres magistrados), en dicha resolución se mantiene que la regla general de que la existencia de una institución no excluye en modo alguno la plena normatividad de la Constitución.

La sentencia únicamente establece una posible excepción, si bien discutible, pero que en todo caso no cabría aplicar a la institución militar. El Tribunal Constitucional afirma que sólo cabe la excepcionalidad en la aplicación de los mandatos, principios y valores constitucionales. el caso de que la institución resulte jurídicamente simbólica o inocua (lo que no es el caso de la institución castrense). Así, en dicha resolución (FJ 15) se afirma que: 
admisible si -y sólo sí- resulta compatible con los contenidos de la propia norma suprema. La doctrina del Alto Tribunal, si bien referida a otros ámbitos (derechos históricos y títulos nobiliarios), bien pueden aplicarse a la institución militar. No en vano se trata de instituciones que por sus connotaciones políticas y/o históricas presentan dificultades para ubicarse en el Estado constitucional. Así, el Tribunal ha señalado que no pueden mantenerse la tradición y la historia - de indudable peso en el ámbito castrense- si son incompatibles con los mandatos y principios constitucionales, pues la Constitución se aplica aún para situaciones previas a su existencia ${ }^{78}$. Asimismo, el Alto Tribunal ha señalado que el hecho de que una institución persista tras la entrada de la Constitución, incluso en virtud de su reconocimiento expreso, no implica la inmunidad de la institución respecto de la normatividad constitucional. Toda institución debe adaptarse al orden

“... los valores sociales y juridicos contenidos en la Constitución y, por tanto, con plena vigencia en el momento actual, necesariamente han de proyectar sus efectos si estuviésemos ante una diferencia legal que tuviera un contenido mate. rials.

En consecuencia, la sujeción constitucional de la institución será plena siempre que pueda implicar un contenido no simbólico o inocuo, material, tal es el caso de la institución militar (su proyección juridica en forma de disciplina, unidad, valores militares, tiene un claro contenido material, por lo cual queda siempre vinculada por la Constitución.)

78 En este sentido resulta conveniente recordar lo afirmado por el Tribunal Constitucional y efectuar su traslación para el ámbito militar:

"El carácter de norma suprema de la Constitución, a la que están sujetos todos los poderes del Estado (art. 9) y que resulta del ejercicio del poder constitucional de pueblo español, titular de la soberania nacional, y del que emanan todos los poderes del Estado (art. 1.2 CE) imposibilita el mantenimiento de situaciones juridicas (aun con una probada tradición) que resulten incompatibles con los mandatos y principios constitucionales. La Constitución [... es] una norma del poder constituyente que se impone con fuerza vinculante general en su ámbito, sin que queden fuera de ella situaciones "históricas" anteriores. En este sentido, y desde luego, la actualización de los derechos históricos supone la supresión, o no reconocimiento, de aquellos que contradigan los principios constitucionales. "(sentencia 76/1988, de 26 de abril, FJ 3, relativa a los "derechos históricos").

"... ha de recordarse que el carácter histórico de una institución no puede excluir, por sí sólo, su contraste con la Constitución. Pues si los principios y valores de ésta informan la totalidad de nuestro ordenamiento, la consecuencia es que la Norma fundamental uimposibilita el mantenimiento de instituciones juridicas (aun con probada tradición) que resulten incompatibles con los mandatos y principios constitucionales". (Sentencia 126/1997, de 3 de julio, FJ 8, preferencia del varón en la sucesión de títulos nobiliarios〉. 
constitucional, al ethos constitucional democrático, de los valores y principios reconocidos en la ley de leyes ${ }^{79}$.

\section{LA SIGNIFICACIÓN CONSTITUCIONAL QUE SE DERIVA DEL HECHO DE QUE LAS FUERZAS ARMADAS SEAN UNA INSTITUCIÓN JURÍDICA}

\section{El reconocimiento y alcance de las Fuerzas Armadas como institución}

\section{A) El acogimiento de las Fuerzas Armadas a los caracteres de una institución}

La mayoría de quienes han sostenido el carácter institucional de las FAS lo aducen en virtud del entendimiento de que éstas forman una institución ${ }^{80}$, en el sentido de las construcciones institucionalistas del Derecho esgrimidas por Hauriou, Romano o Renard ${ }^{81}$. Fernández

79 En este sentido merece la pena recordar las consideraciones realizadas en los votos particulares formulados a la sentencia 126/1997:

"Una simple observación de lo sucedido al entrar en vigor la Constitución de 1978 muestra con toda claridad que una buena parte de las instituciones existentes en aquella fecha pervivieron con posterioridad a la misma pero que no se consideraron inmunes a la Constitución, sino que tuvieron que adaptarse al nuevo orden constitucional —desde la familia y el matrimonio, en el ámbito más privado, hasta, por ejemplo, los derechos históricos a los que se refiere la disposición adicional primera de la Constitución-". (Voto formulado por los magistrados Pi-Sunyer y Vives Antón)... "su pervivencia dependerá en buena medida del grado en que sean susceptibles de incorporar, junto a reconocimientos históricos marcados por el espiritu de cada época, el de otros valores que nos resulte más próximon (Voto formulado por el magistrado Cruz Villalón)

80 Con la excepción de MARTinez López-MuÑIz, José L., "Fuerzas Armadas y administración pública..." cit. págs. 2701-2725, que mantiene una visión institucional de las FAS se excluye expresamente de entre quienes sostienen la caracterización institucional de las FAS con base a las teorias de Hauriou, Romano o Renard.

81 Estos caracteres, pueden sistematizarse en los siguientes: 1- Idea de la obra a realizar; 2- Poder organizado en conformidad con la óptima realización de los fines a realizar, manteniendo su unidad sustancial. Disposición de los medios adecuados para el cumplimiento del fin, susceptibilidad de manejar, utilizar, organizar y arbitrar tales medios; 3- Manifestaciones de comunión en la idea, que entraña la armonía de las voluntades bajo la dirección de un jefe; 4-Estatus objetivo de los que pertenecen a la institución; 5- Según la formulación de mayor envergadura técnica de Santi Romano, se añade el carácter de que la institución debe tener su propio ordenamiento juridico; 6- Renard afirma que también se precisa que la situación de los miembros se fije por un status objetivo que aquéllos no pueden cambiar por un acto de voluntad. 
Segado es quien de forma más completa ha señalado cómo las FAS se acogen fácilmente a los caracteres definitorios de una institución ${ }^{82}$; son varios los autores institucionalistas que perpetran la misma operación ${ }^{83}$, para concluir afirmando que las FAS son una institución.

Por el contrario, Suárez Pertierra considera que "no se cumple uno de los caracteres que, desde mi punto de vista, recoge la idea de institución: autonomía de organización, de disposición de medios y de decisión sobre los fines ${ }^{84}$. No obstante, cabe señalar que esta última opinión queda claramente motivada por un lógico rechazo a la negativa significación política que supone un mal entendimiento de que las FAS sean una institución. Superado este temor, entiendo que la autonomía de organización no deviene esencial para que se pueda calificar a las FAS como una institución jurídica. Como afirma Casado, uno de los autores que afirman la naturaleza institucional de las FAS, "las normas legales o reglamentarias concernientes a las fuerzas armadas no son una manifestación de autonomía, sino elementos o piezas del ordenamiento jurídico del Estado, subordinados a los mismos principios constitucionales y comunes y nacidos o derivados de unas únicas e idénticas fuentes de producción jurídica» ${ }^{85}$.

De otra parte, cabe señalar que para afirmar que las FAS son una institución no hace falta acudir a disquisiciones terminológicas ${ }^{86}$. Tam-

82 Asi, FeRnández SegADo, Francisco, «La posición constitucional..." cit., págs. 40-43.

83 Así, Casado Burbano, Pablo, "Las Fuerzas Armadas en la nueva Constitución española", cit. pág. 9; LóPEZ-GARRIDo, Diego, "La posición constitucional..." cit. págs. 949-971, Trillo-FigueroA, "Las Fuerzas Armadas en la Constitución..." cit., págs. 114-115. Aunque de forma bastante breve, también constata que estos caracteres se dan en las FAS; Serrano Alberca, José Manuel, "Comentario al artículo octavo", cit. págs. 129-130. En contra, BARCELONA LLOP, Javier, "La organización militar:..." cit., rebate la consideración institucional negando que en las FAS se den los caracteres de una institución.

En 1965, pese a que afirmase el carácter administrativo de las FAS, LÓPEZ HENAREZ, Vicente, "La Administración militar», cit. págs. 74-81 atendia todos los caracteres de la Administración militar que son precisamente los que definen una institución en su sentido más distante a la visión que aquí se sigue del alcance del concepto (autonomía administrativa y jurídica material, naturaleza política amplia, acantonamiento jurídico-orgánico, autarquía de la organización, limitación en su control, fuerza expansiva de sus principios).

84 Así, en Suárez Pertieraa, Gustavo, "Regulación jurídico-constitucional de las Fuerzas Armadas" cit., págs. 2375-2376.

85 Casado Burbano, Pablo, "Las Fuerzas Armadas en la nueva Constitución española», cit. pág. 9.

86 La terminología empleada por los textos normativos es un argumento esgrimido frecuentemente por quienes sostienen una postura institucionalista 
poco hace falta, perderse en la significación que adquiere el hecho de que el artículo principal relativo a las FAS (el art. $8 \mathrm{CE}$ ) se incluya en el Título preliminar ${ }^{87}$, pues, a mi juicio, en lo que hay que detenerse es en la propia regulación contenida en éste $y$ otros preceptos constitucionales.

(ver, Elorriaga, Gabriel, "El artículo 8 de la Constitución..." cit. pág. 2547 y TrilloFigueroA, "Las Fuerzas Armadas en la Constitución..." cit. págs. 111 y 112 inota a pie n. 14), si bien; este último autor reconoce que de ello no puede pensarse en una concepción institucional de los Ejércitos en el sentido técnico que él propugna). En los textos legales vigentes, puede advertirse el empleo del término «institución". Así, expresamente en las Reales Ordenanzas, en el epigrafe que designa el Título primero del Tratado primero de dicha norma $\rightarrow$ "De la Institución militar»-, así como en sus artículos 10 y 17. Del mismo modo, el Código Penal Militar incluye un título dedicado a "Delitos contra la Nación Española y contra la Institución militar" (Título IV del Libro segundo, artículos 85 a 90). La Ley Orgánica del Régimen disciplinario militar también emplea el término desde su primer artículo.

Como se habrá apreciado, desde el inicio de este estudio, no se ha eludido el empleo del término "institución" a la hora de referir a las FAS, de hecho, aquí se sostiene la admisibilidad juridico-constitucional de la categoria institucional, por lo cual no comporta paradoja alguna el empleo de este término. Únicamente, por rigor, se ha mantenido la distinción del empleo sociológico y jurídico del mismo.

Menor explicación tiene Guaita MartorelL, Aurelio, "Los derechos fundamentales..." cit., cuando hace empleo del mismo, el mismo advierte -ver pág. 581 - que sólo lo hace desde el punto de vista sociológico no jurídico. Esta consideración realizada por Guaita nos revela la poca consistencia que tiene la negación absoluta del reconocimiento jurídico de una institución. El problema, pues, consiste en advertir la significación jurídica que comporta dicho reconocimiento.

87 Para algunos autores, la ubicación en el Título preliminar es uno más de los argumentos para afirmar que las FAS son una institución. Así, FernÁNDEz SEGADO, Francisco, "La posición constitucional..." cit. pág. 43; Trillo-Figueroa, "Las Fuerzas Armadas..." cit., pág. 105, LóPEz-GARRIDo, Diego, "La posición constitucional..." cit., pág. 958. Cabe destacar la decisiva importancia - del todo desenfocada- que atribuye a esta ubicación BARCELONA LLOP, Javier, "La organización militar..." cit., -que mantiene una posición administrativista- es crucial, ver, págs. 72 y ss. Dado que confiere a este hecho gran importancia, acaba concluyendo que "El artículo 8 de la Constitución ha de entenderse, pues, carente de contenidos jurídicos reales en la medida en que destruye la unidad sustancial de la organización militar.»(La cursiva es mía). No obstante, autores declarados como institucionalistas niegan la relevancia de la ubicación constitucional. LAFUENTE-BALLE, José María, El Rey y las Fuerzas Armadas en la Constitución, EDERSA, Madrid, 1987, pág. 344; Casado Burbano, Pablo, "Las Fuerzas Armadas en la nueva Constitución Española", en Revista Española de Derecho Militar n. 36, julio diciembre de 1978, págs. 7-41, pág. 8, quien afirma que esta ubicación "carece de especial significado jurídico". 


\section{B) ¿Se reconoce una garantía institucional sobre las Fuerzas Armadas?}

La concepción institucional no se distancia de la conocida técnica alemana de la "garantía institucional" ${ }^{88}$. Paralelamente a la consideración de las FAS como institución se ha pretendido afirmar que sobre los Ejércitos recae esta garantía ${ }^{89}$. A mi juicio, resulta más que dudosa

88 Sobre las garantias institucionales, ver, Sснмm, Carl, Teoría de la Constitución, traducido por F. Ayala, 2. ed., Madrid, Alianza, 1982, págs. 175 y ss. En España véase LUCAS VERDÚ, en Nueva Enciclopedia Jurídica, voz "Garantías institucionales", Tomo X, Francisco Seix, Barcelona, 1960, págs. 541 y ss. y, fundamentalmente, cabe remitir al trabajo de PAREJo Alfonso, Luciano, Garantía institucional y autonomías locales, Instituto de estudios de administración local, Madrid, 1981, págs. 17 a 56 . Ahí se contiene la mejor doctrina alemana existente sobre la técnica de la garantía institucional. Véase también GalLEgo ANABITARTE, Alfredo, Derechos Fundamentales y Garantías Institucionales, análisis doctrinal y jurisprudencia: (derecho a la educación, autonomia local y opinión pública), Civitas -UAM, Madrid, 1994; BAÑo, José M, "La distinción entre derecho fundamental y garantía institucional en la Constitución española», en Revista Española de Derecho Constitucional, n. 24, 1988, págs. 155 y ss.; Martin Retortillo, Lorenzo y De Otto Pardo, lgnacio, Derechos fundamentales y Constitución, Civitas, Madrid, 1988, págs. 83 y ss. y 99 y sS. JIMÉNEZ BLANCO, Antonio, "Garantias institucionales y derechos fundamentales en la Constitución", en Estudios sobre la Constitución española. Homenaje al profesor Eduardo García de Enterria, Vol. II, Civitas, Madrid, 1991, págs. 635-649.

Del mismo modo es tenida en cuenta la recepción de esta figura jurídica por parte de nuestro Tribunal Constitucional. Así ocurre desde la sentencia 4/1981, de 28 de julio, sobre las Diputaciones provinciales, en la que se sentó doctrina al efecto. En diversas ocasiones ha seguido empleando el Tribunal esta técnica, así de entre ellas, cabe citar la sentencia 83/1984, de 24 de julio, relativa a la garantía de la libertad empresarial; la sentencia 13/1985, de 31 de enero, sobre la publicidad procesal; la sentencia 104/1986, de 17 de julio, sobre la libertad de información como garantía democrática de la opinión pública libre; la sentencia, importante desde el plano dogmático, 26/1987, de 27 de febrero, sobre la autonomía universitaria; la sentencia 213/1988, de 11 de noviembre, sobre la autonomía municipal. Incluso nuestro Tribunal ha reconocido garantías institucionales fuera de la Constitución en el ordenamiento preconstitucional, como así consideró al antejuicio en la sentencia 156/1989, de 19 de octubre. Entre las más recientes sentencias en las que se ha reconocido la aplicación de la garantía institucional se puede mencionar la sentencia 37/1994, de 10 de febrero, en ésta se reconoció sobre el Sistema de Seguridad Social en virtud del artículo 41 de la Constitución.

89 Ver, López-GARRIDO, Diego, "La posición constitucional de las Fuerzas Armadas", cit. pág. 959, categoriza a las FAS como una "institución de relevancia constitucional", partiendo de dicha categorización concluye este autor que las FAS "parecen ser acreedoras de la protección que confiere la técnica de la garantia institucional" (ver, ob. cit. pág. 961). Este posicionamiento ha tenido algún eco doctrinal, así como posiciones abiertamente contrarias. 
la aplicabilidad dè esta técnica en el ámbito militar; de un lado por su inutilidad ${ }^{90}$, de otro lado por las connotaciones políticas que ello pudiera conllevar ${ }^{91}$.

En todo caso, ha de subrayarse ahora que el reconocimiento de la existencia de una garantía institucional sobre las FAS no podría suponer una merma de la normatividad de toda la Constitución sobre la institución garantizada. Y es que una garantía institucional (concebida frente a la acción del legislador), en modo alguno puede garantizar lo que la Constitución excluye ${ }^{92}$. De ahí que incluso aplicando la técni-

Así, en su favor, Otto y PARdo, Ignacio de, Derecho Constitucional. Sistema de Fuentes, cit. Tal afirmación se contiene en la pág. 31 sin ninguna argumentación (dado que el objeto de la obra es bien otro). En las págs. 32 y 33 , afirma que la constitucionalización minuciosa de las FAS respondió a "la necesidad de satisfacer a grupos bien concretos, como ocurre con la garantía institucional de las Fuerzas Armadas nada menos que en el Título Preliminar." En contra de su aplicación sobre las FAS se ha decantado LOPEZ RAMÓN, Fernando, La caracterización jurídica..., cit., págs. 369 y ss.

90 Cabe tener en cuenta que esta técnica juridica surge cuando se exige una función de preservación o aseguramiento superior al mero efecto normativo que de suyo resulta de la Constitución por su posición jerárquica (Ver, PAREJo ALFonso, Luciano, Garantía institucional... cit. pág. 32). Lo que no tiene sentido es emplear tal garantía para proteger por medio de ella la existencia de unas FAS acomodadas al régimen constitucional; $y$ éste es el motivo que aduce López-GARRIDO, Diego, en «La posición constitucional...» cit. págs. 956, para aplicar tal garantía.

Entiendo que la existencia y funciones de las FAS quedan garantizadas, simplemente, por el valor normativo que de suyo tiene la Constitución.

91 . Esta técnica debe ser excluida en tanto en cuanto mediante ella se pretenda reconocer cualquier tipo de autonomia política de las FAS, contraria al principio de supremacía civil. Cabe recordar que el empleo usual de esta técnica viene especialmente referido a la protección de esferas de libertad o autonomía tanto para las personas (derechos y libertades) como para las instituciones (universidades, diputaciones, municipios, etc.). La garantía no preserva la existencia formal de la institución, sino un marco objetivo de autonomía frente al legislador y al ejecutivo para garantizar sus componentes básicos (Ver, PAREJo Alfonso, Luciano, Garantía institucional... cit. pág. 24 y ss.). No resulta aconsejable, pues, acudir a la misma por lo que hace referencia a las FAS, en tanto en cuanto coadyuvaria a juridificar alguna esfera de autonomia política militar.

Los mismos efectos que deduce López Garrido de la aplicación de la técnica de la garantía institucional parecen querer exculparse de toda sospecha antidemocrática (LóPEZ-GARRIDO, Diego, en "La posición constitucional..." cit. págs. 961).

${ }_{92}$ La eficacia de una garantía institucional sólo se desarrolla desde el plano infraconstitucional, no tiene sentido que la Constitución quedase constreñida por una garantía (Ver, Parejo Alfonso, Luciano, Garantía institucional... cit. pág. 34). Lo que no puede suponer la garantía constitucional es una exención de la sujeción constitucional. 
ca de la garantía institucional sobre las FAS los elementos propios de esta institución (disciplina, valores, neutralidad, etc.) sólo quedan garantizados en la medida en que sean admisibles constitucionalmente armonizándose con el resto de reglas y mandatos de la ley de leyes ${ }^{93}$.

\section{La evolución de la caracterización jurídica de las Fuerzas Armadas por nuestro Tribunal Constitucional}

Es momento ahora de apreciar la posición de nuestro Tribunal Constitucional respecto de la categorización de las FAS como institución o administración, y lo que es más importante, cabe apreciar la proyección jurídica que ha tenido para el máximo intérprete una u otra concepción de los Ejércitos.

Puede señalarse que, por lo general, cuando el Tribunal Constitucional recoge en sus sentencias la expresión "Administración militar" hace referencia al aparato burocrático de las FAS y del Ministerio de Defensa, y no al conjunto de las FAS $^{94}$. Este empleo de la noción

93 Ésta sería la única dimensión juridica admisible que tendría la posibilidad de que sobre las FAS se aplique la técnica de la garantía institucional. Por ello, no se comparten los argumentos contrarios a la misma realizados por LóPEz RAMón, Fernando, La caracterización jurídica... cit.,. pág. 370, pues no debe considerarse que la protección constitucional de los valores militares, la disciplina militar, etc. "per se, sería aberrante y marcharía completamente al margen del tenor integro de la Constitución".

No puede excluirse a priori la admisibilidad de elementos propios de las FAS; su admisibilidad se hace depender de lo que la propia Constitución disponga. No es "aberrante" admitir que las FAS tengan una noción singular de la disciplina y la jerarquía, que exista un honor militar constitucionalmente admisible (es decir, efectivamente funcional), tampoco marcha completamente al margen de la Constitución que se dé en las FAS una también particular afección al sentimiento nacional (siempre y cuando, por ejemplo, la concepción militar de la Patria no vulnerase contenido constitucional alguno - derechos lingüísticos, sistema autonómico, etc.).

94 Asi, el Tribunal Constitucional hace referencia explícita a la "Administración militar» por cuanto al acto administrativo que impone la obligación de prestar el servicio militar (FJ 3, sentencia 15/1982, de 23 de mayo) los recursos propiamente administrativos (FJ 3 de la misma) o recursos disciplinarios (ver, sentencia 11/1993, de 11 de marzo FJ 1). También el Tribunal Constitucional hace referencia a la "Administración" militar en relación a los actos de admisión o inadmisión para acceder a las FAS (ver, sentencia 216/1991, de 14 de noviembre, FJ 4); también se alude a la "Administración" castrense para aludir una afección de bienes a las FAS 
"Administración militar» de forma restrictiva supondría una clara connotación institucional ${ }^{95}$. También resulta significativa la alusión a la "Administración militar" por el Tribunal Constitucional respecto de todo lo relacionado con el ámbito disciplinario ${ }^{96}$. Ello es debido, a mi juicio, al tenor del art. 25.3 CE, uno de los que con claridad impele a reconocer la naturaleza administrativa de las FAS. Sin embargo, el Tribunal no suele emplear la calificación de "Administración militar» en relación a los caracteres propios de las FAS, su especial naturaleza o las funciones (no propiamente administrativas) que llevan a cabo los Ejércitos, es decir, las de naturaleza propiamente ejecutiva. Así pues, se advierte que, quizá de forma subconsciente, el Tribunal sóstiene una percepción institucional de las FAS, pues acude a su calificación como institución a la hora de señalar los caracteres esenciales, naturales $y$ propios de los Ejércitos.

No obstante, en diversas ocasiones el Tribunal ha hecho uso indistinto de los términos "institución" y "administración" ${ }^{97}$ y lo que es más importante, en algunas resoluciones ha afirmado expresamente la caracterización administrativa de las FAS (en concreto, en la sentencias 123/1988, de 26 de junio o la sentencia 18/1994, de 20 de enero ${ }^{98}$ ). Se

(Ver, sentencia 2/1993, de 14 de enero, sobre vehículos afectos a la Administración militar, FJ 5); también el tribunal emplea la noción "Administración" en relación a cuestiones relativas al funcionariado civil de la Administración de Defensa (ver, sentencia 111/1984, de 28 de noviembre, FJ 2).

95 Una "Administración militar" como meramente relativa al aparato burocrático y servicial de las FAS implica un claro seguimiento de la concepción institucional de las FAS. Esta reducida "Administración militar" no incluiría a los Ejércitos en sí, esta Administración seria a la que hace referencia el articulo $97 \mathrm{CE}$; por lo tanto, sólo el Ministerio de Defensa y el aparato burocrático de las FAS quedarían bajo la dirección del Gobierno. Asimismo, las FAS (en tanto que no son Administración) no quedarían sujetas a los principios a los que queda sujeta ésta (arts. 103 y ss. CE), con lo que se mitigaría la normatividad constitucional para la Institución militar.

96 En la primera de sus sentencias al respecto (sentencia 31/1985, de 5 de marzo, FJ 5) el Tribunal hizo alusión al aspecto sancionador de la Administración militar. Referencias a la "Administración" militar en razón de esta materia sancionadora se aprecian, también, en la sentencia 44/1983, de 24 de mayo, o en la sentencia 19/1988 de 16 de febrero.

97 Así, en la sentencia 44/1983, de 24 de mayo (FJ 1), o en la sentencia $123 / 1988$, de 26 de junio (FJ 5), se advierte una indistinción no sólo en el uso terminológico "administración»-uinstitución", sino en la proyección institucional que tiene tanto la alusión a las FAS cuanto a la "Administración militar".

98 En la sentencia 123/1988 se afirma que "Las particularidades que poseen las Fuerzas Armadas no excluyen, como señalan los escritos del Gobierno y Parlamento baleares, su carácter de Administración Pública." (FJ 5) El Tribunal también 
infiere así que no existe incompatibilidad entre una y otra categorización para el máximo intérprete.

Por cuanto a lo que particularmente aquí interesa, el alcance del carácter institucional de las FAS como "derogador" de los contenidos constitucionales hay que significar, con Domínguez Berrueta, que en los primeros años de jurisprudencia constitucional se daba una desmedida remisión a los "caracteres propios de la Institución militar"; de este modo, se justificaban ciertas excepcionalidades constitucionales ${ }^{99}$. La sola referencia a "la seguridad nacional", "las necesidades de la defensa", "el carácter esencial de la disciplina para la Institución militar" y otras cláusulas o técnicas de naturaleza semejante (como la existencia de una "relación de especial sujeción»" ${ }^{100}$ ) parecian ser argumento suficiente para admitir la singularidad castrense en cada caso enjuiciada sin mayores justificaciones siempre requeridas en el Estado de Derecho. No obstante, se puede constatar que la evolución jurisprudencial ha hecho remitir la contundencia inicial de las construcciones institucionalistas. En la sentencia 60/1991, de 14 de marzo

expresamente la sentencia 236/1994, de 20 de julio, afirma en su FJ 3 la integración de la Administración militar en la Administración Pública al afirmar que "Diferentes son también las misiones y funciones asignadas a una y otra Institución len referencia a las FAS y la Guardia Civil ... ] e igualmente distinto es su encuadramiento en el seno de la Administración y dependencia orgánica"

99 Ver, Domínguez-BerRueta, Miguel y otros, “El control jurídico-constitucional de la transición militar..." cit. en especial véanse las págs. 2965-2984. Entre otras, en las siguientes resoluciones se aprecia este uso, por parte del Tribunal, del término "Institución militar": auto 375/83, de 30 de julio, sentencia 44/1983, de 24 de mayo, sentencia 97/1985, de 29 de julio, sentencia 180/1985, de 19 de diciembre, sentencia 107/1986, de 24 de julio y la sentencia 114/1987, de 6 de julio.

${ }^{100} \mathrm{Al}$ respecto de la categoria de las relaciones de especial sujeción, resultan básicos los estudios de GaRcia MACHO, Ricardo, Las relaciones de especial sujeción en la Constitución española, Tecnos, Madrid, 1992; López Benitez, Mariano, Naturaleza y presupuestos constitucionales de las relaciones especiales de sujeción, Civitas, Madrid, 1994; Lasagabaster HeRrarte, Iñaki, Las relaciones de sujeción especial, Civitas, Madrid, 1994; JIMÉnEZ-BLANCO, Antonio, "Notas en torno a las relaciones de sujeción especial: un estudio jurisprudencial del Tribunal Supremon, en Revista la Ley, tomo 2, año 1988, págs. 989-993. En fechas próximas puede seguirse mi reciente estudio Cotino HuEso, Lorenzo, "Relaciones de especial sujeción: su diversa evolución en Alemania y España. (Particular seguimiento de la jurisprudencia constitucional, contencioso-administrativa y militar de la presente década)", en Revista del Poder Judicial, (3." época) n. ${ }^{9} 55,2000$ (I), págs. 355-388.

En todo caso, por lo que ahora concierne, cabe señalar que la mera alegación de la existencia de una relación especial -como la militar- parecía eximir de la necesidad de justificar y fundamentar las limitaciones a los derechos de los sometidos, o para relativizar el principio de legalidad en la regulación de los mismos. 
(FJ 6), se afirmó que «no es aceptable la visión de lo castrense como un mundo aparte, $y$ del Derecho militar como el ordenamiento interno de una institución separada que configura una sociedad distinta, perfecta y completan. Sin embargo, esta acertada percepción no ha impedido la continuidad de una línea restrictiva a la hora de reconocer derechos y libertades en el ámbito militar basada en una concepción institucional ${ }^{101}$.

A pesar de ello, poco a poco se formulan mayores justificaciones para admitir las diversas particularidades que se dan en la esfera castrense. El paso decisivo no es otro que aplicar las categorías generales, en especial, la necesidad y la proporcionalidad, que se aplican en todos los ámbitos constitucionales. Estas mismas categorias son también centro nuclear de las exigencias generales para considerar admisibles los límites a los derechos y libertades de los militares (necesidad, congruencia, proporcionalidad y respeto del contenido esencial) ${ }^{102}$. La lenta evolución apreciada en el peso del institucionalismo por parte del Tribunal Constitucional parece ir por detrás de la evolución seguida respecto de las llamadas "relaciones de especial sujeción» ${ }^{103}$. La cerca-

101 El continuismo institucionalista restrictivo de derechos y libertades del militar se aprecia en las siguientes sentencias del Tribunal Constitucional de la presente década: sentencia 101/1991, de 13 de mayo, sentencia 371/1993, de 13 de diciembre, sentencia 72/1994, de 3 de marzo, sentencia 270/1994, de 17 de octubre, sentencia 288/1994, de 27 de octubre, y la sentencia 14/1996, de 29 de enero.

102 El propio Tribunal Constitucional en la importante sentencia 120/1990, de 27 de junio, (caso huelga de hambre de los GRAPO), recordaba, con una extraordinaria concisión, los pilares básicos que suponen estas teorías generales de los límites y de la delimitación de los derechos y libertades:

"A tal fin, como ya ha reiterado en diversas ocasiones este Tribunal, conviene tener presente, de una parte, que sólo ante los límites que la propia CE expresamente imponga al definir cada derecho o ante los que de manera mediata o indirecta de la misma se infieran al resultar justificados por la necesidad de preservar otros derechos constitucionalmente protegidos, pueden ceder los derechos fundamentales (SSTC 11/1981, FJ 7; 2/1982, FJ 5; 110/1984, FJ 5), y de otra que, en todo caso, las limitaciones que se establezcan no pueden obstruir el derecho "más allá de lo razonable" (STC 53/1986, FJ 3), de modo que todo acto o resolución que limite derechos fundamentales ha de asegurar que las medidas limitadoras sean "necesarias para conseguir el fin perseguido" (SSTC 62/1982, FJ 5; 13/1985, FJ 2) y ha de atender a la «proporcionalidad entre el sacrificio del derecho y la situación en que se halla aquél a quien se le impone" (STC 37/1989, FJ 7) y, en todo caso, respetar su contenido esencial (SSTC 11/1981, FJ 10; 196/1987, FJ 4, 5, 6; 197/1987, FJ 11), si tal derecho aún puede ejercersen.

${ }_{103}$ Sobre esta categoría, especialmente atinente ál ámbito de los derechos fundamentales, se volverá en su momento. Baste adelantar que se trata de una técnica que, en paralelo a la alusión de la existencia de una institución, parecía eximir de la necesaria justificación de los límites a tales derechos fundamentales. 
na sentencia 151/1997, de 29 de septiembre parece indicar que, pese al retraso en adoptar (y adaptar) la evolución jurisprudencial para la relación jurídico-militar, la aplicación de las técnicas generales de limitación y delimitación de los derechos y libertades se abre camino para el mundo de los cuarteles ${ }^{104}$.

Como consecuencia de lo expuesto, puede concluirse afirmando que el Tribunal Constitucional niega los extremos institucionalistas, si bien en sus sentencias se advierte el peso - a veces desmedido-de estas construcciones, que poco a poco va remitiendo.

\section{3. ¿Cuál es la significación jurídica del reconocimiento de las Fuerzas Armadas como una institución?}

Llegados a este punto, puede ya afrontarse el hecho de que las FAS sean una institución regulada por el Derecho militar (que incluye

104 En esta resolución el Tribunal da definitiva entrada a las referidas técnicas generales, haciendo expresa referencia a las mismas en su FJ 5 Del mismo modo, el Alto Tribunal encauza la singularidad del mundo militar dentro del plano axiológico y principial que la Constitución impone.

Ello no significa que esta sentencia excluya las posibles limitaciones a los derechos y libertades para el buen funcionamiento de los Ejércitos, como garantía de la seguridad del Estado. Sin embargo, de esta resolución se desprende con nitidez el surgimiento de una nueva época en la se da cabida a los postulados que en el presente estudio se invocan.

Se trataba de juzgar la admisibilidad de la expulsión de un Capitán del Ejército por consentir el adulterio de su esposa. El Tribunal ponderó el derecho a la intimidad del sujeto frente al bien constitucional del honor militar, llegando a la conclusión de que se había violado el derecho del militar a su vida íntima. No obstante la decisión final, resultan extraordinarias las reiteradas cautelas con las que el Alto Tribunal ha emprendido esta tarea. En diferentes ocasiones se afirma que "la realización de conductas deshonrosas para el militar, el Arma o Cuerpo al que pertenece o para los Ejércitos pueda, en determinadas circunstancias constituir un límite al ejercicio del derecho a la intimidad personal y familiar" (FJ 5). En dos ocasiones más se repite esta advertencia en el FJ 6; en la última de ellas se considera que "No cabe negar a priori que, en determinadas circunstancias, conductas intimas como la que dio lugar al actual proceso puedan realmente afectar al honor militar. Sin embargo [...] a la luz también de los valores y principios constitucionales, hoy la concurrencia de estas circunstancias en el caso examinado no puede darse por supuesta, sino que debe justificarse con todo detalle."

Puede entenderse como un preludio a esta evolución del Alto Tribunal la sentencia 56/1997, de 17 de marzo, en la que se concedió el amparo al recurrente $y$ se redefinieron los términos de la prisión provisional en el ámbito militar. No obstante, no puede eludirse el hecho de que en aquella ocasión el demandante era el Coronel Perote, por lo cual se trataba de un asunto muy politizado. 
en su cúspide, como se dijo, el Derecho constitucional militar). Es momento de recordar e incidir en la idea de que el hecho de que se reconozca la existencia de una institución no es "inocuo" jurídicamente. La existencia de una institución si que tiene relevancia jurídica; implica, ni más ni menos la integración en el ámbito jurídico de la realidad que subyace tras las formas y estructuras normativas. Una visión institucionalista de las FAS completa la determinación de lo dispuesto en las normas y lo hará en plena conformidad con el resto de lo dispuesto con la Constitución. Es, precisamente, en el ámbito constitucional donde la influencia del "método" o "enfoque" institucional no es, en absoluto, despreciable. Los caracteres propios de las Constituciones (brevedad, ambigüedad, flexible interpretación, etc.) hacen necesario el apoyo institucional a la hora de determinar los contenidos constitucionales de lo expresado en la norma suprema. $Y$ precisamente en el ámbito militar la influencia de la comprensión institucional no es baladí. Dada las lacónicas referencias constitucionales al fenómeno castrense ${ }^{105}$, el apoyo institucional para determinar el tratamiento constitucional de la materia militar supone un válido y útil apoyo.

Ahora bien, sólo en la medida en que la institución supere el filtro constitucional, podrá desplegar su virtualidad jurídica. $Y$ no resulta sencillo constatar la admisibilidad constitucional de una institución y de los elementos inherentes a la misma ${ }^{106}$. Para ello, en primer lugar, se debe percibir si la institución (en nuestro caso, las FAS) ha sido reconocida o excluida por la Constitución (ya sea implícita o explícitamente). El siguiente paso a seguir - básico en materia militar-consiste en apreciar cuáles son los elementos que de suyo comporta la institución. De entre estos elementos hay que distinguir los que resulten esenciales, es decir, de los que depende la recognoscibilidad de la misma (por ejemplo, sin disciplina no existen ejércitos) o simplemente los elementos históricos y/o naturales de la institución (es decir, las extensiones naturales de la institución que provienen del propio desarrollo histórico, por ejemplo, el "honor militar»" ${ }^{107}$ ).

105 En este sentido, Casado Burbano, Pablo, "Las Fuerzas Armadas en la nueva Constitución Española», en REDM n.@ 36, julio diciembre de 1978, págs. 7-41, en concreto, pág. 8 afirma que todas las constituciones parecen rehuir de la regulación de las FAS, como algo incómodo, tabú; no se las trata como a una parte más de la Administración.

106 Para ello, puede servir de orientación apreciar el camino seguido por los votos particulares formulados a la mencionada sentencia 126/1997 (títulos nobiliarios).

107 Para el ámbito de las FAS esta distinción entre elementos esenciales, naturales e históricos es básica. La institución militar no pierde eficacia, sino que la 
Una vez advertidos estos elementos, debe ser analizado el régimen de compatibilidad de la institución y sus caracteres propios con los contenidos normativos constitucionales. Así, si los elementos esenciales se estiman incompatibles con la ley de leyes, la institución, por necesidad, quedaría excluida por la norma fundamental ${ }^{108}$ (si la Constitución negase la posibilidad de la disciplina militar, estaría negando la existencia de los ejércitos, lo cual, claro está, no es el caso) ${ }^{109}$. Si la norma suprema no impide los elementos esenciales de la institución, ésta se mantiene pese a que decaigan sus proyecciones naturales o tradicionales, pero no esenciales ${ }^{110}$ (las FAS persisten pese a que no se mantenga la concepción de la virilidad militar de antaño, su tradicional participación en el poder político o un desfasado concepto del honor militar).

Sin embargo, cabría también la posibilidad de que el constituyente hubiese inmunizado a la institución —en nuestro caso la militarde la plena sujeción a lo dispuesto en la ley de leyes. Esta excepciona-

gana, si se actualizan sus elementos basilares; en cambio, tradicionales caracteres militares, no esenciales, bien pueden decaer por exigencia constitucional. No se puede negar que la concepción de la disciplina ha variado históricamente y lo sigue haciendo actualmente, tampoco puede negarse que el honor militar que se admitirá constitucionalmente resulta sustancialmente distinto al medieval honor caballeresco, que llegó, incluso, al presente siglo. Como se advierte al final de este estudio, la incorporación de los valores constitucionales al tradicional "espíritu militar" resulta incontestable. Aún es más, el propio principio de neutralidad política no tiene actualmente nada que ver con sus proyecciones históricas. La mejor garantía de la supremacía civil, a mi juicio reside en la plena integración social del militar, $y$ no en la merma de sus derechos.

108 En referencia a los títulos nobiliarios, en los votos particulares no se duda en afirmar que:

"Para determinar si un determinado elemento de este conjunto normativo es contrario a la Constitución resulta ineludible descartar que la propia institución se encuentre en contradicción con la Constitución vigente, porque, si así fuera, sería la institución toda la que habría de caer, y no sólo uno de sus elementos aislados". (Cruz Villalón).

${ }_{109}$ Obviamente, como ya se ha señalado, no es el caso de la institución castrense, reconocida expresamente en la Constitución, a la vez que alguno de sus elementos basilares (la disciplina se reconoce en los artículos 28 y 29 CE), así como mediante el principio de jerarquia de la Administración, artículo $103 \mathrm{CE}$.

110 Asi se aprecia en los votos particulares aludidos en relación con la institución nobiliaria:

"la desigualdad que caracteriza a los títulos nobiliarios no es sustancial, sino meramente histórica" (Viver Pi-Sunyer y Vives Antón). "Para comenzar, no nos encontramos ante un elemento basilar de la institución [...] estamos exclusivamente hablando de un elemento, en definitiva, secundario del sistema" (Cruz Villalón). 
lidad exigiría, por necesidad, la forma expresa"11. Como se verá en el siguiente apartado de este estudio, la Constitución no inmuniza expresamente a las FAS del resto de su articulado ${ }^{112}$.

En conclusión, la verdadera dimensión juridica que tiene el hecho de afirmar que las FAS son una institución es el reconocimiento constitucional implícito de estos elementos inherentes de la misma (eficacia, disciplina, valores militares, subordinación política, etc.). Obviamente, este reconocimiento constitucional de tales elementos sólo alcanza hasta donde los mismos sean compatibles con el resto de la ley de leyes.

\section{Unas notas al respecto de la institución militar a la que da vida jurídica la Constitución española: el modelo constitucional de Fuerzas Armadas}

Tal y como se ha manifestado a lo largo del presente estudio, todos los caracteres que conforman a las FAS como una institución histórica o sociológica quedan a expensas de la Constitución, que es la que dota de vida jurídica a la institución militar. Subrayar la primacía de la ley de leyes sobre el ámbito militar supone partir de la Constitución a la hora de examinar jurídicamente los Ejércitos. Se afirmaba en apartados anteriores que lo central es analizar el modelo constitucional de FAS (y no seguir los modelos sociológicos), pues bien, de lo que se trata es de apreciar cómo configura la Constitución a la institución militar (sin partir de una idea de FAS preconcebida, sino de las FAS tal y como han sido reconocidas constitucionalmente). En esta dirección, hay que poner de manifiesto una "coincidencia" normalmente inadvertida: los parámetros que describen un modelo sociológico de FAS son, prácticamente, los mismos caracteres que llevaban a afirmar que las FAS son una institución jurídica. Así pueden examinarse, por ejem-

111 Cruz Villalón, en su voto particular formulado por afirmar que «el propio Texto constitucional puede establecer excepciones explicitas a los principios $y$ derechos proclamados de forma general, sin que ello entrañe ningún "esquizofrénico" problema de constitucionalidad". Consideración semejante se realiza también en el texto de la sentencia aludida (FJ 7), así, se sitúa como ejemplo la excepción al principio de igualdad del art. $14 \mathrm{CE}$ que se efectúa en el art. $57.1 \mathrm{CE}$, al preferir al varón sobre la mujer en la sucesión a la Corona.

112 Me remito a la "visión estructuralista" que se contiene en el posterior apartado. Sirva como ejemplo de lo afirmado el art. 28 CE que habilita al legislador para que excepcione el derecho de sindicación a los sujetos militares. 
plo, los parámetros elaborados por sociólogos como Fleckenstein ${ }^{113} \mathrm{o}$ las notas que caracterizan a las FAS como institución a juicio de Fernández Segado ${ }^{114}$. Y lo más interesante a nuestros efectos es que unos y otros rasgos definitorios quedan a expensas de la Constitución, que es la que dota de vida jurídica a la Institución militar e impone toda una serie de exigencias respecto de todos y cada uno de estos elementos definitorios conformando, de este manera, el modelo constitucional de FAS ${ }^{115}$. De este modo, los elementos que resultan básicos desde la perspectiva de la eficacia (modelos sociológicos) y aproximan el Derecho a la realidad (institución jurídica) pasan a constituir los puntos de mira para operar un examen jurídico-constitucional que de otra manera podría resultar superficial $y$ formalista.

113 Este autor configura la finalidad de los Ejércitos (puntos primero — "Finalidad de las fuerzas armadas"-, segundo - "Tarea del soldado"- y sexto "Motivación vocacional"-), naturaleza (punto tercero); posición política de los Ejércitos y la posible participación política de sus miembros (punto noveno — "Soldados y política" - y décimo - "Grupos de interés profesional-sindical»-); relaciones divergentes o convergentes de las FAS con la sociedad civil y la composición social de los Ejércitos (punto séptimo - "Relaciones con la sociedad civil»-; el concepto de la vocación militar y las condiciones de la profesión (disciplina, valores, uniformidad, salario, horario de servicio: puntos cuarto - "Valores del soldado"-, quinto - "Concepto de la vocación militar»-, sexto - "Motivación vocacional»-, octavo - "Uniforme»-, undécimo - "Salario»-y duodécimo - "Horario de servicio"-). FLECKENSTEIN, Bernhard, "Alemania Federal", cit., págs. 232-253, en concreto puede seguirse el esquema en la pág. 235.

114 Asi, 1.o, idea-fuerza sobre la que reposa la institución, la finalidad de las FAS, 2. específica forma de organización y de un régimen jurídico singular del personal $y$ tenencia de un específico código de valores asi como un ordenamiento jurídico propio que es el Derecho militar, 3. las FAS son un conjunto social perfectamente delimitado frente al exterior, 4.․ singular status del personal, en aras de la eficacia, ver, Fernández Segado, Francisco, "La posición constitucional..." cit., págs. 40-43.

115 Precisamente, a resultas de una sistematización de estos criterios definitorios de un formato de Ejército y de la institución militar, se desarroila el libro El Modelo constitucional de Fuerzas Armadas (capítulo segundo: "Los fines para los que pueden ser constitucionalmente empleadas las Fuerzas Armadas", capítulo tercero: "Posición que corresponde a las Fuerzas armadas en el sistema político diseñado en la Constitución", capítulo cuarto: "Exigencias constitucionales respecto de la composición social de las Fuerzas armadas y sus relaciones con el resto de la sociedad", capítulo quinto: "Exigencias constitucionales respecto de la disciplina militar y la organización interna de las Fuerzas Armadas" y, por último, el capitulo sexto: "Valores castrenses, educación y enseñanza militar a la luz de la Constitución»). 


\section{UNA VISIÓN ESTRUCTURAL FORMAL. ¿PRESCRIBE EXPRESAMENTE LA CONSTITUCIÓN UNA PECULIAR SUJECIÓN PARA EL ÁMBITO MILITAR?}

\section{Un mismo propósito, unas nuevas coordenadas}

El objeto básico del presente estudio - tantas veces aludidono es otro que afirmar la plena sujeción de las FAS y del ordenamiento militar a la Constitución. Ha quedado ya constatado que lo que aparecía como principal enemigo de esta plena normatividad "aquellas connotaciones institucionalistas"- no merma en absoluto la completa vinculación a la ley de leyes. A pesar de ello, respondiendo a este ánimo de asentar definitivamente la vinculación total de nuestra Constitución para el ámbito militar, cabe ahora analizar la cuestión desde una perspectiva diferente a la anterior visión institucionalista. Se trata ahora de aseverar la vinculación de la norma suprema para la institución de las FAS desde una perspectiva estructuralista, formal. Siguiendo la perspectiva institucional se ha afirmado que sería posible que la propia Constitución inmunizara o eximiera a una institución (como la militar) de la normatividad constitucional. Se señalaba entonces que para ello era imprescindible que tal autolimitación de la normatividad constitucional se estableciese de forma expresa ${ }^{116}$. Pues bien, a continuación se pretende advertir si, partiendo de lo expresado en la norma suprema, resulta posible sostener una sujeción de lo militar a la ley de leyes menor que la debida en otros ámbitos de la esfera pública.

$Y$ es que esta posible relajación de la normatividad constitucional podría encontrarse en las menciones contenidas en los artículos 8 -en su apartado segundo- y 117 -en su apartado quinto- de nuestra norma fundamental, donde se preceptúa una conformidad a los "principios constitucionales" para el ámbito militar ${ }^{117}$. El objeto cenla acompaña.

116 Al respecto, véase supra lo afirmado en la nota $n .{ }^{\circ} 111$ y en el texto que

117 Artículo 8:

[...] 2. Una ley orgánica regulará las bases de la organización militar conforme a los principios de la presente Constitución. "

Artículo 117:

"[...] 5. El principio de unidad jurisdiccional es la base de la organización y funcionamiento de los Tribunales. La ley regulará el ejercicio de la jurisdicción militar en el ámbito estrictamente castrense y en los supuestos de estado de sitio, de acuerdo con los principios de la Constitución". 
tral de la siguiente reflexión se centra en si tal referencia puede interpretarse de forma negativa, esto es, como la mera sujeción a tales principios en tanto tales, es decir, la sumisión a los contenidos de la ley de leyes no como mandatos concretos sino como principios jurídicos de mayor flexibilidad ${ }^{118}$. Esta lectura negativa, como es obvio, relajaría la proyección constitucional para el ámbito militar. Cabe advertir que con relación al ámbito militar y de las FAS, no parece ajena la mención del artículo 52 de la Constitución italiana de 1947, por cuanto dispone que "L'ordinamento delle Forze armate si informa allo spirito democratico della Republica". En aquel marco, se ha dado una lectura positiva y una negativa del mismo respecto de la plena normatividad constitucional ${ }^{119}$. Aunque con algunas diferencias, pue-

118 Al respecto del diferente alcance de una norma ya como regla ya como principio ver, ALEXY, Robert, Teoría de los derechos fundamentales, Centro de estudios Constitucionales, Madrid, 1993, en general todo el Capítulo tercero ( "La estructura de las normas de derecho fundamental", págs. 81-170) y en particular ver las págs. 82-87, las afirmaciones concretas se contienen en las págs. 85-86. Se sigue también la distinción entre reglas y principios efectuada por ZAGREBELSKY, Gustavo, El derecho dúctil. Ley, derechos, justicia, Trotta, (2. ed. 1997), págs. 109 y ss. No obstante, ello no supone admitir la desnaturalización que, a mi juicio, efectúa este autor del carácter normativo de la Constitución.

${ }_{119}$ Se trata, pues, de apreciar si el ordenamiento militar simplemente "se informa" de un laxo "espíritu democrático" o, precisamente, dichas expresiones implican un reforzamiento de la sujeción a lo dispuesto en la norma suprema italiana. Sobre el precepto italiano y su significación, véase LABRIOLA, Silvano, "Difesa nazionale e sicurezza dell Stato nel diritto pubblico italiano", en Rivista Trimestrale di Diritto Pubblico, 1979, n. 4 págs. 904 y ss.; Bettinello, Ernesto, Comentario al artículo 52.1 y 2, en Pasouino, G. y otros, Rapporti politici, (Tomo 1) artículos. 48-52, Zanichelli editore, Bologna; Soc. ed. del Foro italiano, Roma, 1992, págs. 70-149; el resto de posiciones existentes al respecto pueden apreciarse brevemente en Blanouer, David, Ciudadano y soldado. La Constitución... cit., págs. 210-214.

En sentido negativo se ha decantado PACE, en relación con la libertad personal admite que el apartado $3 .^{9}$ del artículo 52 , presta fundamento suficiente para derogar en el ámbito de las FAS el reconocido derecho a la libertad personal. En la misma dirección, si bien respecto del principio de igualdad, PALADín afirma que el art. 52.3 configura el ordenamiento militar como un ordenamiento especial que deroga al general en la medida necesaria para la satisfacción de los intereses de las Fuerzas Armadas.

En una posición intermedia puede encontrarse a LABRIOLA (cfr. ob. cit. págs. 920-921), quien dedujo del art. $\mathbf{5 2 . 3}$ un principio de reserva de ley para lo referente a lo militar facultándose así la regulación por parte del Parlamento y los debidos controles de constitucionalidad.

Desde la perspectiva más favorable a la plena vinculación constitucional, debe citarse a Giannini, Massimo S., "I Pubblici Poteri negli Stati Pluriclasi", cit. 
de afirmarse que una expresión paralela se encuentra en nuestra Constitución en sus artículos 8.2 y $117.5^{120}$.

Es menester señalar, no obstante, que, pese al interés del tema y su profundo calado jurídico, en España el debate no se ha centrado en la posible significación que pueden adquirir estos preceptos en relación con la plena sujeción a la Constitución. La discusión se ha desviado hacia la tan manida ubicación en el Título preliminar de la regulación básica de las FAS (art. $8 \mathrm{CE}$ ) y la consideración institucional de las mismas; curiosamente, parece haberse optado por rehuir del propio tenor constitucional. Por contra, pese a esta desatención doctrinal, entiendo que resulta aconsejable detenerse en apreciar el alcance de lo regulado en dichos preceptos, por cuanto en alguna medida pudiesen implicar alguna flexibilización de la normatividad constitucional para el ámbito militar.

págs. 393., aprecia en este precepto que lo que distingue al poder en el Estado actual es el abandono del reconocimiento de un ámbito de autonomía al ordenamiento militar. MorTatı, Constantino, Instituzioni di Diritto Pubblico, tomo II, Padova, CEDAM, 1976, pág. 1141, (citado en Blanquer, David, Ciudadano y soldado. La Constitución... cit., pág. 213), entiende que el art. 52.3 revela la voluntad constituyente de romper con todo ligazón con la tradición, ya que ésta consideraba al ejército no sólo como un ordenamiento propio, sino además como un ordenamiento con fuerza de excluir la vigencia de algunos principios fundamentales que garantizan las libertades e la persona. Modugno, Franco, en la voz, "Pluralitá degli ordinamenti", de la Enciclopedia del Diritto, tomo XXXIV, Milano Giuffré Editori, 1985, págs. 28-29, en este sentido, afirma que las normas y los principios constitucionales no permiten la reconstrucción del ordenamiento militar como una entidad separada, particular o interna respecto al ordenamiento general; las FAS son una más de las estructuras administrativas del Estado, si perjuicio de estar dotada de particulares competencias y características. Rossı, afirma que las FAS son uno de los órganos de la Administración, por lo cual, no pueden tener voluntad autónoma, así se desprende -afirma - de la expresa forma de Estado diseñada por la Constitución italiana(cfr. ob. cit. pág. 154-155). En consecuencia, el art. 52.3 supone la exigencia de salvaguardar un núcleo inviolable o contenido esencial de los derechos constitucionalmente garantizados a todos los hombres (cfr. ob. cit. pág. 167).

120 Se dan algunas diferencias, el ámbito de referencia normativa es distinto. En el caso italiano se hace referencia a todo el ordenamiento jurídico militar y se le exige conformidad con un "espíritu democrático". En el caso español la referencia está realizada no para todo el ordenamiento militar, sino para dos ámbitos concretos: la ley orgánica que regule las bases de la organización militar y la ley que regule el ejercicio de la jurisdicción militar; además el parámetro de conformidad exigido resulta en mayor medida concretable, por cuanto se trata de uprincipios constitucionales", que tienen un carácter de abstracción menor que el de la referencia al "espiritu democrático». 


\section{La significación de la remisión a los "principios constitucionales" contenida en los artículos 8.2 y $117.5 \mathrm{CE}$ : doctrina $y$ jurisprudencia}

\section{A) La regla general del art. 9.1 CE y sus especificaciones}

El valor normativo de la Constitución ${ }^{121}$ lo tiene la norma en $\mathrm{si}^{122}$, y el mismo es reconocido como regla general en el art. 9.1, regla general que, a la vez, resulta reiterada en diversos preceptos del articulado de la ley de leyes. Estas manifestaciones concretas de la normatividad constitucional conciernen tanto la actuación de los poderes públicos $^{123}$, cuanto a la sujeción de las normas a la Constitución ${ }^{124}$.

121 Al respecto del valor normativo de la Constitución, entre otros, véase, OTTO Y PARDO, Ignacio de, Derecho Constitucional. Sistema de Fuentes, (reimpresión) Ariel, Barcelona, 1995. págs. 14 y ss., 44 y ss. y 76 y ss., AA. VV., La Constitución Española y las Fuentes del Derecho, (3 vol.), Dirección General de lo Contencioso del Estado, IEF, Madrid, 1979, in toto. BöCKENFÖRDE, Erns-Wolfgang, Escritos sobre Derechos Fundamentales, Ed. Nomos-Verlagsgesellschaft, BadenBaden, 1993, págs. 37 y ss., Grimm, Dieter, "La Constitución como fuente del Derechon, en, BaratTa, A. y otros, Las Fuentes del Derecho, Anuario de la Facultad de Derecho, Estudi General de Lleida, Eds. Universitat de Barcelona, Barcelona, 1983, págs. 13-27, Pérez Royo, Javier, Curso de Derecho Constitucional, cit., págs. 26 y ss. y Las Fuentes del Derecho, Tecnos, (4. ed.), Madrid, 1988, págs. 29 a 48; GARCíA DE ENTERRIA, La Constitución como norma y el Tribunal Constitucional, (3." ed.) Civitas, Madrid, 1985, págs. 63-104, recientemente, de este autor, "El valor normativo de la Constitución de 1978", en La Constitución Española de 1978. 20 años de democracia, Congreso de los Diputados-Centro de Estudios Constitucionales, Madrid, 1998, págs. 283-303 y en "El valor normativo de la Constitución española", en Revista de Derecho Politico, n.o 44, 1998, págs. 31-44; o Álvarez Conde, Enrique, "La incidencia de la Constitución en el ordenamiento juridico", en Administraciones Públicas y Constitución. Reflexiones sobre el XX Aniversario de la Constitución Española de 1978, Instituto Nacional de Administración Pública, 1999, págs. 19-35.

${ }_{122}$ Se siguen así, las manifestaciones realizadas por OTTO Y PARDO, Ignacio de, Derecho Constitucional. Sistema de fuentes. cit. págs. 24-26, en el sentido de que "el carácter supremo de la Constitución es presupuesto de la validez del art. 9.1 " (ob. cit. pág. 25) $-\mathrm{y}$, obviamente, del resto de concreciones de la misma que se advierten en el texto constitucional-.

123 El principio de constitucionalidad, para los poderes públicos, al margen del propio art. 9.1, se ratifica en preceptos como el 97.1, 103.1 y 106.1, que sujetan la actuación del Gobierno y de la Administración a la Constitución y al resto del ordenamiento jurídico. La vinculación de la Corona a la Constitución se reitera en preceptos como el 62 y 63, y la de las Comunidades Autónomas, al margen de otras disposiciones (como los artículos 133, 147), deriva, con nitidez, del artículo 155. 
Particular atención requieren estas reiteraciones de la normatividad constitucional cuando se establecen respecto de algunos ámbitos materiales concretos (partidos, sindicatos, centros privados de enseñanza, estados de excepción, Corona, ámbito autonómico ${ }^{125}$ ), como es el caso de las FAS en los artículos 8.2 y $117.5 \mathrm{CE}$. Mención singular merece, también, el art. 53.1, pues supone la clara voluntad constitucional no sólo de reforzar la normatividad de los derechos fundamentales para los poderes públicos, sino que se conmina a tales poderes a la propia efectividad de los derechos y libertades. La atención presente se debe centrar en descubrir cuál es el significado $y$ alcance de estas previsiones constitucionales que reiteran la sujeción a la Constitución y, de forma concreta, apreciar el alcance de la sujeción a los principios constitucionales dispuesto para el ámbito militar.

\section{B) La referencia a los "principios constitucionales" contenida en los arts. 8 y 117 CE para nuestra doctrina}

En el momento en el que se aprobaba la ley de leyes, Casado Burbano se detenía sobre la significación de las alusiones al los uprincipios constitucionales" contenidas en los artículos mencionados. Res-

124 La vinculación constitucional, al margen del propio art. 9.1, es reiterada respecto de los tratados internacionales y de las demás normas que emanan de los poderes del Estado en el ámbito de sus competencias constitucionales, asi, en los artículos 95 (Tratados internacionales), el 97.1 (reglamentos) o el 161 (leyes y disposiciones con fuerza de ley).

125 Así, se pueden encontrar algunas remisiones particulares de la sujeción constitucional para algunos ámbitos materiales de ordenación, en los cuales el constituyente creyó conveniente recordar la vinculación constitucional, por tratarse de áreas en las que fuese preciso despejar posibles dudas o evitar construcciones jurídicas tendentes a evadir la normatividad constitucional.

Estas remisiones particulares de la sujeción a la Constitución son las siguientes: "dentro del respeto a la Constitución" en los artículos 6 y 7 -partidos, sindicatos y asociaciones empresariales-; "dentro del respeto a los principios constitucionales", artículo 27.6 -en materia de enseñanza-; "dentro de los términos de la presente Constitución" en el artículo 55 -estados excepcionales-; la misma técnica mencionada utilizada en los artículos 62 y 63 uen los términos previstos en la Constitución" o "de conformidad con la Constitución y las leyes" -competencias reales-; "de acuerdo con la Constitución" en el artículo 87; "de acuerdo con la Constitución y las leyes", artículo 133; "dentro del marco establecido por la Constitución», artículo 147 -ámbito autonómico-. Como se verá, al igual que las citadas, las remisiones a la conformidad a los principios constitucionales contenidas en los arts. 8.2 y 117.5 , deben considerarse recordatorios de la plena sujeción constitucional. 
pecto del artículo octavo, afirma que "Sin duda, las fuerzas armadas son una estructura de autoridad, cuyo soporte básico es la disciplina, por lo que, en principio, es difícil aplicar a su organización todas las normas rectoras de una comunidad organizada democráticamente, pero ello no quita, sin embargo, el que muchos de los principios inspiradores de estas normas puedan y deban presidir la vida y la actividad castrense, siempre que no mermen la capacidad operativa de los Ejércitos que constituye su razón de ser" ${ }^{126}$. Por cuanto a la alusión en el artículo 117 señalaba "que implica que aquellos principios que presiden la actuación de los Tribunales ordinarios deben presidir también la actuación de esta jurísdicción especial»» ${ }^{127}$.

Más negativa seria la percepción en estos momentos desde filas próximas a los militares, como la posición de Pellón, quien se preguntaba «pero ¿qué principios van a recogerse? ¿todos los enunciados o los que se desprenden del propio texto constitucional?" ${ }^{128}$, él mismo se contestaba afirmando que "lo que se ha querido decir es que el conjunto de disposiciones sobre los Ejércitos, es decir, el ordenamiento militar, no puede ser algo contrapuesto o esencialmente distinto del ordenamiento general del Estado y, en particular, de la constitución, que las fuentes del Derecho Militar deben derivarse, y engarzarse en el sistema jurídico que informa la nación, pero esto no impide operar las adaptaciones exigidas por el ámbito específico al que se destinan. En suma, el ordenamiento militar ha de inspirarse en los principios constitucionales, debe informarse de su mismo espíritu democrático, pero no puede adoptar los mismos métodos democráticos" "129. Siguiendo a Prosper afirmaba que "La democratización de la función pública se acaba a la puerta de los cuarteles" ${ }^{130}$.

Lucas Verdú afirma que los "principios constitucionales" referidos en el artículo 8 no sólo son los contenidos en el Título l, sino también los principios explícitos e implícitos contenidos en todo el texto constitucional ${ }^{131}$. Serrano Alberca agrupa tales principios en tres

126 Casado Burbano, Pablo, "Las Fuerzas Armadas en la nueva Constitución española", cit. pág. 13.

127 Ibidem pág. 37.

128 Pellón, Ricardo, "La libertad de opinión en las Fuerzas Armadas", en Revista Española de Derecho Militar n. ${ }^{\circ} 37$, enero-junio de 1979 , págs. $15-91$, en concreto, pág. 23.

129 lbidem págs. 23-24.

130 WEIL, Prosper. "Arme et fonction publique", en la Defense National, P. U. F. 1958, pág. 195, ahí citado. 
grandes grupos: los principios y valores aplicables con carácter general que están reconocidos a lo largo de todo el texto constitucional; los principios propios de la Administración reconocidos en los artículos 103 a 106 y, en tercer y último lugar, los principios especialmente aplicables a las FAS, esto es, la subordinación y obediencia de las FAS al Gobierno, el mando supremo del Rey, el apartidismo y la especialidad de la jurisdicción militar ${ }^{132}$. A este último grupo de principios Fernández Segado añade el derecho y el deber de defender España y la configuración de un estatuto juridico peculiar para los miembros de las FAS bajo los principios nucleares de unidad, disciplina $y$ jerarquia ${ }^{133}$.

Por su parte, López Ramón, en coherencia con su construcción administrativa de las FAS, subraya que la remisión del artículo 8.2 a la organización de las FAS de conformidad con los principios viene referida a los principios que rigen la actuación de la Administración (arts. 103 y ss.) $)^{134}$. Respecto del art. 117 CE San Cristóbal señalaba que se trataban de todos los principios del título IV del Poder Judicial, con el resto de los principios básicos del Estado de Derecho ${ }^{135}$.

En consecuencia, desde la perspectiva de estos autores, bajo la calificación de uprincipios" se recogeria toda la regulación constitucional atinente a lo militar. Ésta es la posición que aquí se sostiene, pero con una diferencia jurídica importante: para estos autores, dicha regulación constitucional parece contar únicamente con la eficacia de principios jurídicos, cuando, tal y como a continuación se sostiene, la eficacia de la Constitución en lo militar no es otra que la que la propia

131 Ver, Lucas Verdú, Pablo, «El Título I del Anteproyecto Constitucional. (La fórmula política de la Constitución)", en Estudios sobre el Proyecto de Constitución", Centro de Estudios Constitucionales, Madrid, 1978, págs. 9 y ss. En concreto pág. 23.

132 Ver, Serrano Alberca, José Manuel, "Comentario al artículo octavo"..." cit., págs. 125-129.

133 Ver, Fernández Segado, Francisco, "La posición constitucional..." cit., pảg. 67. Coincide con conjunto de principios BLANCO VALDÉS, Roberto, La ordenación constitucional de la defensa,... cit., págs. $80-84$, sin perjuicio de su afirmación general, contenida infra.

134 Ver, López RAMón, Fernando, La caracterización jurídica... cit., concretamente en la pág. 332, desarrollando la acomodación a los principios administrativos de tal página a la 352. Esta idea la ratifica en su trabajo López RAMÓN, Fernando, "Principios de la ordenación constitucional de las Fuerzas Armadas», cit. pág. 258, donde señala que la referencia sería inútil si no viniese referida concretamente a los principios del artículo $103 \mathrm{CE}$.

135 San Cristóbal Reales, Susana, La jurisdicción militar... cit., pág. 17. 
norma confiere a sus preceptos, es decir, ya como valores, ya como principios, ya como reglas o mandatos.

Más próximas a lo que a continuación se sostiene son las posiciones mantenidas por Blanco Valdés, López Garrido, o Blanquer. El primer autor de los citados afirma que la remisión a los principios constitucionales en el artículo octavo plantea «al legislador ordinario el mandato de derogar lo que por muchos ha sido llamado el ordenamiento jurídico castrense, el derecho militar, entendido como un sector del ordenamiento inmune o situado al margen de los valores y principios generales que informan la totalidad del ordenamiento jurídico del Estado" ${ }^{136}$. En un sentido cercano, López Garrido, siguiendo a Vergotti$\mathrm{ni}$, cree que el mandato del artículo 8.2 indica el propósito de garantizar una completa permeabilidad entre el ordenamiento del Estado y el militar, tradicionalmente separado, eliminando las reservas que pueda haber entre el poder Ejecutivo y el vértice militar ${ }^{137}$. Para Blanquer, la remisión a los principios constitucionales significaría la necesaria integración y compatibilización de la seguridad del Estado con los derechos fundamentales ${ }^{138}$. Supondría, pues, un recordatorio de que, si bien las necesidades de la defensa son un bien constitucional que merece particular protección, los derechos y libertades gozan de una especial relevancia constitucional; de la referencia a los "principios" -afirma-, cuanto menos, no puede deducirse inferioridad alguna respecto de la defensa nacional.

\section{C) La escasa atención del Tribunal Constitucional a las referencias de sujeción a los principios constitucionales}

Son escasas las consideraciones vertidas por el Tribunal Constitucional al respecto del significado que tienen las alusiones a los principios constitucionales contenidas en los artículos 8.2 y $117.5 \mathrm{CE}$. Por cuanto al primero de los preceptos, la única alusión de "los principios y valores constitucionales" (art. 8.2 CE) servía para apoyar la "revisión

136 BLANCO VALDÉs, Roberto, La ordenación constitucional de la defensa,... cit., pág. 81. Cabe recordar no obstante la afirmación inicial de este autor en la que parece admitir la existencia de un ordenamiento aislado, que hay que ureducir al mínimo", ya cit. pág. 24.

964.

137 Ver, LópEz-GARRIDO, Diego, "La posición constitucional...» cit., págs. 963-

138 Ver, Blanquer, David, Ciudadano y soldado. La Constitución... cit., págs. 234-235. 
profunda" que el texto constitucional ha impuesto sobre la regulación del servicio militar (sentencia 69/1991, de 14 de marzo, FJ 5 ${ }^{139}$ ). Así pues, se trataba de un mero apoyo inconcreto que ponia de manifiesto la influencia general de la Constitución sobre un aspecto propio del ámbito de la defensa, el servicio militar.

Mayor importancia han tenido las alusiones a los principios constitucionales respecto de la jurisdicción castrense. A decir del Tribunal "el art. 117.5 CE [...] impone al legislador una transformación radical de su configuración y alcance, dejándola sometida a los principios constitucionales relativos a la independencia del órgano judicial y a las garantías sustanciales del proceso y de los derechos de defensa" (sentencia 60/1991, de 14 de marzo, FJ 3) ${ }^{140}$. De este modo, la referencia a los principios se identifica con el seguimiento de mandatos concretos como lo son los derechos y garantías básicas; y éstos no se tienen en cuenta en condición de principios. Así, tras la anterior afirmación, el Tribunal ha llegado a concretar que, en virtud de la alusión a los principios constitucionales, los órganos de la jurisdicción militar "están vinculados a los derechos y libertades fundamentales como todos los poderes públicos y que en el ámbito de su competencia [...] han de tutelar igualmente los derechos y libertades señalados en el art. 53.2 de la Constitución." (sentencia 113/1995, de 6 de julio, FJ 6). En consecuencia, la referencia en el artículo 117.5 a los principios constitucionales ha sido adecuadamente seguida por el Tribunal, pues no se ha interpretado en el sentido de que el legislador y la propia jurisdicción militar sólo se tuvieran que sujetar a los contenidos constitucionales en tanto que meros principios jurídicos ${ }^{141}$. En alguna ocasión, no obstante se ha dado una imperfección técnica, como

139 En esta sentencia se afirmaba que «El texto constitucional, [...] impone una revisión profunda de la regulación del Servicio Militar obligatorio - para ponerla en consonancia con los principios y valores constitucionales (art. 8. 2 CE)."

140 Esta referencia se reitera en la sentencia 204/1994, de 11 de julio (FJ 4) $y$ en la sentencia 113/1995, de 6 de julio (FJ 7 ).

141 Cuestión diferente, claro está, es que la jurisprudencia constitucional haya sido escrupulosa a la hora de apreciar si la jurisdicción militar en su actuación o la regulación de la misma por el legislador han seguido fielmente los mandatos constitucionales, en particular, el respeto de los derechos y garantias del militar. Sobre la jurisdicción militar, entre otros, Fernández Segado, Francisco, "Nuevo perfil orgánico y competencial de la jurisdicción militar", en AA. VV, Jornadas de Estudio... cit. págs. 2855-2903. Curso del CGPJ sobre la Jurisdicción Militar, publicada en Cuadernos de Derecho Judicial, monográfico n.․ 2, 1992; especialmente ofrece una visión desarrollada y crítica del respeto de los principios constitucionales San Cristóbal Reales, Susana, La jurisdicción militar. De jurisdic- 
cuando el Alto Tribunal afirmaba que "los órganos de la jurisdicción militar deben ejercer su potestad jurisdiccional "de acuerdo con los principios de la Constitución" (art. 117.5, in fine, CE) "142. Ello supone, sin duda una lectura descuidada de este precepto ${ }^{143}$, puesto que la referencia a los principios constitucionales viene referida a la regulación legal de la jurisdicción militar, y no a los principios como el único material constitucional con el que han de trabajar la justicia castrense. Cabe señalar que esta misma confusión, se produce en el primer artículo de la Ley Orgánica 4/1987, de 15 de julio, de la Competencia y Organización de la Jurisdicción Militar, en el que se preceptúa que "la jurisdicción militar, integrante del Poder Judicial del Estado, administra justicia en nombre del Rey, con arreglo a los principios de la Constitución y a las leyes". No obstante, en su artículo 5 se afirma que "la Constitución [...] vinculan a los órganos de la jurisdicción militar".

3. La posición aquí sostenida: los arts. 8.2 y 117.5 CE evitan cualquier negación de la plena normatividad constitucional para el ámbito militar

\section{A) La poca operatividad que podría alcanzar una lectura negativa de lo dispuesto en los artículos 8.2 y 117.5 CE}

Una lectura negativa de estos preceptos supondría entender que en ellos se establece una flexibilización del alcance normativo de la Constitución. Se entendería que para el ámbito militar las reglas y mandatos contenidos en la ley de leyes no regirían como tales reglas y mandatos (que indefectiblemente deben ser cumplidos) sino en calidad de meros principios jurídicos (cuyo cumplimiento se puede graduar y relativizar, pues queda a expensas de las posibilidades reales y jurídicas).

ción especial a jurisdicción especializada, Comares, Granada, 1996, en dicha obra no se duda en considerar que no se ha respetado la independencia e inamovilidad de los jueces militares (págs. 151-204), así como que la jurisdicción militar vulnera tanto el principio de unidad (págs. 237-243) cuanto el principio de exclusividad (págs. 244-265).

${ }_{142}$ Sentencia 113/1995, de 6 de julio 8 , (FJ 6).

143 El cual, cabe recordar que dispone: "La ley regulará el ejercicio de la jurisdicción militar en el ámbito estrictamente castrense y en los supuestos de estado de sitio, de acuerdo con los principios de la Constitución.» 
Ahora bien, de seguirse esta lectura negativa los resultados serian incoherentes o, cuanto menos, esta presunta reducción a principios del alcance de la ley de leyes, quedaría, por necesidad, muy mer- . mada. En primer lugar, en virtud del artículo 53, para los poderes públi$\cos$ los derechos fundamentales no pueden en ningún caso, quedar reducidos a la mera condición de principios jurídicos; estos derechos quedarían, pues, fuera de un hipotético ámbito de autolimitación de los artículos 8 y $117^{144}$. En segundo lugar, hay que tener en cuenta que toda excepcionalidad debe ser interpretada restrictivamente; de ahí que debería entenderse también de forma restringida el alcance objetivo $y$ subjetivo de estas presuntas mitigaciones de la normatividad de la Constitución. Como consecuencia de esta necesaria lectura restrictiva, por lo que se refiere al art. 8.2, esta hipotética flexibilización sólo alcanzaria a la regulación de las "bases" - sólo las bases ${ }^{145}$ - de la "organización militar" $-y$ no toda la defensa nacional ${ }^{146}-$. Además, esta

144 Sobre la funcionalidad de lo dispuesto en el art. $53.1 \mathrm{CE}$, véase MARTIN Retortillo, Lorenzo, "Eficacia y garantía de los derechos fundamentales», en Estudios sobre la Constitución española. Homenaje al profesor Eduardo García de Enterría, Vol. II, Civitas, Madrid, 1991, págs. 585-633, en la pág. 592; Sánchez FerRiz, Remedio, "Algunas reflexiones sobre la efectividad de los derechos", Revista de Derecho Político de la UNED, $\mathrm{n}, 936,1992$, págs. 235-254, en concreto en las págs. 243 y ss.; Medina Guerrero, Manuel, La vinculación negativa del legislador a los derechos fundamentales, Mc Graw Hill, Madrid, 1996, pág. 4 recuerda que «la sujeción general del legislador a la Constitución se hace más intensa cuando están en juego los derechos fundamentales".

Desde aquí se pretende subrayar que el empleo del término "todos" excluye expresamente que en el terreno de lo militar los derechos y libertades sólo actúen como principios jurídicos que el legislador debe respetar.

145 De haber prosperado la rechazada enmienda del diputado GAstón SANZ al artículo 8.2 sí que se entendería que toda la organización militar sería diseñada por ley sujetándose únicamente a los principios constitucionales. Dicha enmienda propugnaba la siguiente redacción: "Una ley regulará la organización militar con arreglo a los principios de la siguiente constitución", véase CorTes Generales. Constitución española... ob. cit. pág. 919. Por ello, respecto del art. 8.2 el legislador sólo regularía conforme a los meros principios las bases de la organización militar, y no toda la organización militar.

Cabe recordar que, precisamente, la única variación existente entre este precepto del anteproyecto y el aprobado finalmente resulta de la variación de lo señalado en cursiva - "dentro de" que pasó a ser "conforme a»-, corrección de estilo que se produjo en la Comisión constitucional del Senado a raíz de la proposición del Sr. Baeza Martos (cfr. Cortes Generales, Constitución española., cit., págs. 9 y 3115 y ss.). El peso del consenso sobre la materia fue abrumador.

${ }_{146}$ El objeto de regulación de la ley orgánica a la que hace referencia el art. 8.2 sólo vendría referido a la organización militar y no a la "defensa nacional» (término cuya amplitud resulta extraordinaria — véase sino la definición incluida 
«autoderogación» del alcance normativo se reduciría a la actuación del legislador orgánico (no a las normas del legislador ordinario, ni a las emanadas del Gobierno ${ }^{147}$ ).

Por lo que concierne a la jurisdicción militar, la conformidad a los principios constitucionales del art. 117.5, debe interpretarse sólo referida a la determinación legal de esta jurisdicción y de su ámbito. Como se ha señalado, el artículo 117.5 en modo alguno puede significar que la jurisdicción militar en el ejercicio de sus funciones sólo tenga en cuenta los principios constitucionales. Como consecuencia de lo expuesto, tanto para el art. 8.2, como para el art. 117.5, el alcance de estas autolimitaciones devendría ciertamente reducido.

en el art. 2 la LODNOM-). En este sentido, LóPEz RAMÓn, Fernando, La caracterización jurídica... cit., pág. 348 acertadamente ha criticado dicha interpretación extensiva del alcance de la reserva orgánica del art. 8.2 CE. Fernández Segado, Francisco, "La posición constitucional..." cit., pág. 65 por contra, entiende que la organización de las FAS no puede desvincularse del concepto de defensa nacional, puesto que las FAS son elemento central de ésta. La doctrina sobre materias conexas asentadas en la sentencia del Tribunal Constitucional 76/1983, de 5 de agosto inclina a pensar la razón del primero; una posible revisión del Tribunal Constitucional podría privar del carácter de orgánico a los preceptos que no atiendan a la organización militar, dado que el legislador no los indicó como debía de haber hecho.

${ }^{147}$ Esta hipotética y específica sujeción constitucional no se daria con las leyes o demás normas que en desarrolio de tales bases, la ley orgánica determine o posibilite. No olvidemos la importancia de esto último, por cuanto el articulado de la referida LODNOM, determina la existencia de un total de dieciséis leyes que desarrollen las bases que en esta norma orgánica se incluyen. En consecuencia, esta presunta flexibilización de la normatividad constitucional no vendria referida respecto de estas leyes de desarrollo.

Según la doctrina, dichas "bases" de la organización militar son los criterios generales, fundamentales por los que ha de regirse la organización militar, no tiene nada que ver con las "bases" de una delegación legislativa (arts. 82-85 CE), ni puede identificarse con las leyes marco (art. 150.1 CE), sino que ha de entenderse como noción material. (En este sentido, Fernández SEGADo, Francisco, "La posición constitucional..." cit., pág. 64, Serrano AlberCa, José Manuel, "Comentario al artículo octavo"... cit., pág. 125 y LÓPEZ RAMÓN, Fernando, La caracterización jurídica... cit., pág. 347 nota a pie n. 56. Del mismo modo lo entendió el legislador al establecer por ley orgánica no el contenido de unas bases a desarrollar por delegación legislativa conforme al los artículos 82 y ss. de la Constitución, sino las bases materiales de la organización de la Administración militar. Asi ha sucedido en las dos ocasiones que se ha regulado por ley orgánica en virtud del artículo 8.2 de la Constitución: en la LODNOM 6/1980 de 1 de julio y en la reforma de ésta por la LODNOM 1/1984, de 5 de enero.) Por ello, la sola conformidad a los principios constitucionales se daría únicamente para con la ley orgánica, y sólo en cuanto determine las bases de la organización militar (no de la defensa nacional). 


\section{B) Una lectura positiva en virtud de la interpretación sistemática}

Una lectura positiva respecto de la normatividad constitucional, implica entender que las expresiones contenidas en los artículos $8.2 \mathrm{~V}$ 117.5 CE. refuerzan el principio de constitucionalidad del art. 9.1 para el ámbito militar. Ésta es, a mi juicio sin duda, la lectura que cabe inferir de lo dispuesto en estos preceptos; una lectura sistemática de la Constitución ${ }^{148}$ es la que nos lleva a esta conclusión.

$Y$ es que tal y como se indicó al inicio de este apartado, en la norma suprema se encuentran una serie de concreciones y reiteraciones de la regla general del art. 9.1 relativas a unos ámbitos materiales concretos (partidos, sindicatos y asociaciones empresariales, educación y enseñanza privadas, estados excepcionales, Corona, Estado de las Autonomías, etc. ${ }^{149}$.) La voluntad es clara en todos los casos, se trata de parcelas en las que, al igual que sucede en el marco militar, por la historia y/o por su propia naturaleza la plena normatividad constitucional pudiera ponerse en entredicho, de ahí que la ley de leyes expresamente reitere su plena normatividad para estos contextos conflictivos. La voluntad constitucional expresada en estos preceptos no persigue otro fin que asegurar y reforzar la plena normatividad, frente a posibles desvirtuaciones que pudiesen darse de la regla general contenida en el art. 9.1 CE.

Así pues, este análisis estructural-formal concluye en la línea de lo ya afirmado en los apartados anteriores: los artículos 8.2 y 117.5 en modo alguno suponen una limitación del alcance normativo de la Constitución para las FAS. Justamente, lo que contienen son unas referencias expresas que aseveran la completa vinculación normativa de la ley de leyes frente a antiguas concepciones que inmunizaban a las FAS $y$ al ordenamiento militar de su sujeción al ordenamiento civil $y$ general. Debe entenderse la remisión a los principios como una garantía que impide interpretación alguna que excluyera a las FAS de su sujeción a la Constitución.

148 Respecto de la interpretación sistemática constitucional, entre otros, véase el trabajo de Alonso García, Enrique, La interpretación de la Constitución, Centro de Estudios Constitucionales, Madrid, 1984; Freixes SAnJuÁn, Teresa, "Una aproximación al método de interpretación constitucional", en Cuadernos de la Cátedra Fadrique Furió Ceriol, n. 4, 1993, págs. 37-50, en concreto, págs. $42-45$ y Álvarez CONDE, Enrique, Curso de Derecho Constitucional (Vol. I), 2.. ed. Tecnos, Madrid, 1996, págs. 159-167

149 Véase supra nota a pie $n .9125$. 


\section{A MODO DE CONCLUSIÓN: \\ CONVERGENCIA SOCIAL, CONVERGENCIA EN DERECHO. EL BINOMIO CONSTITUCIÓN-FUERZAS ARMADAS POR ENCIMA DE LO NORMATIVO}

La plena sujeción constitucional que desde diversas perspectivas se ha defendido a lo largo de este estudio debe suponer la definitiva ubicación de las FAS en el Estado social y democrático de Derecho y, en consecuencia, la plena convergencia civil-militar. Lejos de antiguas afirmaciones que rezaban la incompatibilidad de la democracia y la libertad con los Ejércitos y de los militares con la sociedad ${ }^{150}$, es la propia Constitución la que afirma que tanto en sus funciones, en sus fines $y$ en sus medios debe darse una perfecta avenencia.

En un principio se señaló que los dualismos jurídico y sociológico quedaban íntimamente relacionados; no en vano, tras los dos se escondía la adecuación de las FAS al contexto actual (social, político, económico y jurídico). La necesaria convergencia civil-militar se proyecta sobre el Derecho de una manera insospechada: las construcciones jurídicas específicas que se daban para lo militar deben ceder su puesto a las categorías generales empleadas en Derecho público. Abordar la singularidad jurídico-militar con los parámetros generales ofrece importantes ventajas. Las cláusulas generales de necesidad, proporcio-

${ }^{150}$ Son diversas las consideraciones realizadas acerca de la compatibilidad de los elementos propios de las FAS con la libertad y la democracia. Se ha afirmado de los militares que su pensamiento "se opone a la democracia y que desea organizar la sociedad sobre la base de la cadena de mando. Independientemente de si estas conclusiones son acertadas, el método utilizado para llegar a ellas es, a la vez, subjetivo y arbitrario"(Cfr. Huntington, Samuel P. La mentalidad militar... cit. pág. 187.) Es posible atribuir el carácter antidemocrático o contrario a las libertades a algún sector de las FAS, y especialmente teniendo en cuenta las circunstancias históricas concretas y el peso del protagonismo pasado en la vida política. Si bien, no parece correcto atribuir este carácter como típico de la mentalidad militar. Así, por ejemplo, Giménez Riutord, Domingo, en España: Ejército y Cambio, Miguel Font Editor, Mallorca, 1989, pags. 17 y 18.

En el año 1928, Pumarola escribía (Pumarola Alaiz, Luis, Democracia y Ejército. (Vulgarización sobre los fines y medios del Ejército en la sociedad actual, Católica Toledana, Toledo, 1928. cita de la pág. 32):

"Existe el prejuicio de incompatibilidad entre el Ejército y la Democracia. Realmente ese perjuicio tendria razón de ser si el Ejército hubiera permanecido estacionado y no hubiese sufrido evolución siguiendo la marcha imperiosa del progreso. Todavia hay quien cree que no puede vivir el ejército, sin un poder regulador autocrático de los de arriba, y una obediencia ciega en los de abajo. Nada, sin embargo más opuesto a la realidad". 
nalidad ${ }^{151} y$, en el marco de los derechos y libertades, el respeto de su contenido esencial son herramientas jurídicas suficientes para impulsar la necesaria adecuación del Derecho militar al sistema constitucional. $Y$ lo que es más importante, en modo alguno la verdadera eficacia de la institución militar debe quedar afectada con una correcta aplicación de estas técnicas generales. La necesidad y la proporcionalidad son medios jurídicos básicos que adecuaban la amplia gama de los efectos del principio de necesidad - tan presente en el mundo militar- a las verdaderas exigencias en el Estado constitucional. La misma estructura de estas categorías jurídicas da perfecta cabida a los datos objetivos y empíricos de la realidad, a las verdaderas necesidades de la defensa. A la vez, el método jurídico institucional, no es sino instrumento de acercar adecuadamente las exigencias de los Ejércitos al Derecho.

El Derecho constitucional no da la espalda a la ya aludida "primacía de los hechos" de la que hablaba el Diputado Sr. Solana y con la que se iniciaba este estudio. Antes al contrario, las necesidades de la defensa, la disciplina, incluso el "honor militar", son bienes jurídicos que la Constitución no sólo admite, sino que también protege. No en vano la garantía de estos bienes constitucionales redunda en el mantenimiento del Estado, y no otro que el Estado constitucional. La eficacia de las FAS no tiene por qué quedar desguarnecida pese a que se sitúe en el marco de la necesidad y proporcionalidad, en el contexto del valor preferente de los derechos y libertades y la órbita propia de una "sociedad democrática»" ${ }^{52}$.

151 Entre otros, al respecto de estas exigencias en general, no sólo respecto de los derechos fundamentales, puede seguirse el completo estudio de Álvarez GARcia, Vicente, El concepto de necesidad..., cit., en concreto, págs. $452-458$ (necesidad) y 458-506 (proporcionalidad), así como el monográfico dedicado a la misma en Cuadernos de Derecho Público, INAP, n. 5, diciembre de 1998. Esta perspectiva general es la que particularmente interesa respecto del ámbito militar, pues, si bien la peculiaridad castrense afecta al estatuto del militar de forma usual, no necesariamente deben quedar afectados los derechos y libertades; de ahí que la atención a las claúsulas de necesidad y proporcionalidad desde la perspectiva general resulte de gran interés.

152 Se hace referencia a un típica claúsula de admisibilidad de los límites a los derechos y libertades reconocida en los textos internacionales. Así en la DUDH en su genérico artículo 29.2, en los preceptos que reconocen derechos en el CEDH (arts. 6.1, y 8, 9, 10 y 11) o la fórmula casi idéntica del PIDCP y el PIDESC. Al respecto de las exigencias a los límites a los derechos en el contexto europeo, véase, Freixes SANJUÁN, Teresa, "Las principales construcciones jurisprudenciales del Tribunal Europeo de Derechos Humanos", en Cuadernos de la Cátedra Fadrique Furió Ceriol, n. 11-12, págs. 97-115, en concreto véanse las págs. 101 a 106. 
El empleo de las técnicas generales, ajenas a la excepcionalidad, implicará a la larga la normalización del Derecho militar y su plena adaptación al sistema constitucional; se tratará ciertamente de alcanzar el aludido modelo constitucional de FAS o, en otros términos, la concepción que tiene la ley de leyes de la institución castrense. Se logrará así hacer buena la aseveración de Von der Goltz, quien afirmó que "La organización de las fuerzas militares depende del grado de civilización ${ }^{153}$, y ante este reto queda la civilización de la democracia y los derechos y libertades ${ }^{154}$. Nada mejor, por último, que recordar algunas afirmaciones en relación con la convergencia civil-militar:

"La obra de compenetración y de unión solamente tendrá éxito, si al propio tiempo que la pretenden las leyes y reglamentos, se cumple en las inteligencias y en los corazones" ${ }^{155}$.

"No basta con que formalmente las FAS estén bajo la autoridad jerárquica del Gobierno; es necesario que materialmente, ideológicamente, sociológicamente, las FAS sean una institución integrada en los principios constitucionales democráticos" ${ }^{156}$.

Por ello, cabe finalizar el presente estudio advirtiendo los efectos consiguientes a la plena normatividad de la Constitución. La referencia contenida en los artículo 8.2 y $117.5 \mathrm{CE}$, tal y como se ha apreciado, supone la específica voluntad constitucional de ubicar definitivamente a las FAS en el contexto axiológico y principal que supone la norma de normas. Ya no se trata de sujetar a las FAS y al ordenamiento militar al tamiz normativo de la Constitución. La plena proyección Constitucional para este ámbito trasciende, incluso, del plano puramente jurídico-normativo, impone, indefectiblemente, la necesidad de internizar en las FAS los valores y principios constitucionales, entre los que cobran especial significación, en virtud de los artículos 1.1 y 10.1, los derechos fundamentales y libertades públicas ${ }^{157}$.

153 Así, citado en Pumarola Alaiz, Luis, Democracia y Ejército... cit. pág. 9

154 En este sentido sea válido recordar a BURDEAU cuando afirma que "la democracia sólo accesoriamente se puede considerar una forma de gobierno. Es una filosofía, una religión, un modo de vida, un estilo de relaciones humanas). (cfr. BurDEAU, G. Traité de science politique, (vol. V) L. G. D. J, Paris, 1985, pág. 514, cita recogida en SÁnchez FerRiz, Remedio y Jimena Quesada, Luis, en La enseñanza de los derechos humanos, Ariel, Barcelona, 1995, pág. 24.

${ }_{155}$ Cfr. Pumarola Alalz, Luis, Democracia y Ejército... cit. pág. 37.

156 Cfr. López-GARRIDO, Diego, en "La posición constitucional..." cit. pág. 963.

157 FeRnández SEGADO, Francisco, «El perfil diferencial de la escala de valores de la institución militar", Revista Española de Derecho Militar, n.․ 44-50, enero de 1985-diciembre de 1987, págs. 89-133, pág. 129 ha señalado, sin duda con acierto, 
Precisamente, que la institución militar haga suyos los valores contenidos en la Constitución impide que las FAS constituyan una eficaz arma al servicio de una idea, desnuda, del Estado. Los valores que integra la Constitución son, precisamente, los pilares básicos del objeto de defensa de los Ejércitos —el Estado, y no otro que el social y democrático de Derecho ${ }^{158}$ - . La plena asimilación de estos valores por la institución militar contribuirá, sin duda, a la máxima entrega por parte de aquéllos a quienes la sociedad confía su defensa última ${ }^{159}$.

que la tenencia de una escala de valores es imprescindible para la institución que posee la fuerza legítima del Estado, pues, de faltar ésta se trataria más de una horda o facción armada que de un auténtico Ejército.

158 En este sentido es menester recordar que el Estado constitucional es el objeto de defensa de las FAS, y el mismo cabe percibirlo desde la nueva concepción de la soberanía y de la nación en virtud de la democracia y los derechos y libertades, sobre el tema he tenido ocasión de expresar mi posición en Cotino Hueso, Lorenzo, "Nación política y nación cultural. Una apuesta por el nacionalismo constitucional", en SÁnChEZ FerRIZ, Remedio, El Estado constitucional y su sistema de fuentes, Tirant lo Blanch, Valencia, 2000, págs. 228-231. La necesidad de vincular a las FAS con el "sentimiento constitucional» la he sostenido en "Exigencia del conocimiento de los derechos humanos y los principios democráticos por los funcionarios militares", en AA.VV, Derechos, deberes y responsabilidades en la enseñanza. (Análisis jurídico-práctico a la luz de las exigencias constitucionales), (coord. por Lorenzo Cotino Hueso), Generalitat Valenciana, Valencia, 2000, págs. 329-353.

159 Fernández Segado, Francisco, "El perfil diferencial...", cit. pág. 116 ha afirmado que la política en favor de una Defensa eficaz no sólo incluye la dotación de armas y técnicas a las FAS, sino que, además, debe prestar igual asistencia al mantenimiento de lo que se ha denominado "el plano moral de la defensa". Se quiere subrayar ahora que la asimilación de los valores y principios constitucionales por el estamento armado contribuye inexorablemente al eficaz desempeño de las funciones constitucionales de las FAS. 